\title{
Race to the Top of the Corporate Ladder: What Minorities Do When They Get There
}

\author{
Devon W. Carbado* \\ Mitu Gulati**
}

\begin{abstract}
Racing to the top of the corporate hierarchy is difficult, no matter how qualified or capable the candidate. Producing more widgets than one's competitors is not enough. Negotiating the political landscape of the institution is also required. More specifically, individual corporate officers have to be appeased, powerful interest groups have to be co-opted and made allies, and competitors have to be undermined or eliminated. The more bureaucratic the organization and the more opaque the promotion process, the more important this institutional game to climbing the corporate ladder. This Article identifies the kind of racial minorities or racial types who are likely to play this game well and, consequently, race to the top of the corporation.
\end{abstract}

Identifying these racial types is crucial to making corporations more welcoming to and comfortable for racial minorities. This is because the racial minorities at the top of the corporation ("successful racial types") are in an institutional position to perform discrimination-ameliorative tasks for those on the bottom. Thus, many corporate governance and employment discrimination scholars rest some of their hope for the

* Professor of Law, University of California at Los Angeles. We are grateful to Steve Choi, Adrienne Davis, David Wilkins, Kimberle Crenshaw, Emily Houh, Kim Krawiec, Gowri Ramachandran, Brooks Holtom, Don Langevoort, Laura Morgan, Maureen Scully, Max Shanzenbach, Luke Harris, Frank Rudy Cooper, and Kim Yuracko for a number of long conversations about the issues in this Article. Participants at presentations at Northwestern, Wisconsin, 2004 Academy of Management Meeting, African American Policy Forum's Writer's Workshop, and the 2004 People of Color Conference provided valuable comments. Special thanks to Dorothy Brown for including us in this symposium and to Martha Fineman for her encouragement of our collaboration. Funding for this project was provided by the African American Policy Forum, the Georgetown University Law Center, and UCLA School of Law. The law libraries at UCLA and Georgetown and, in particular, Charles D'Itri, Christopher Knott, and Edeanna Johnson-Chebbi provided exceptional research assistance. Leah Boyd and the editors at Washington and Lee did an excellent job editing the manuscript.

** Professor of Law, Georgetown University. 
establishment of colorblind corporate cultures on the assumption that successful racial types actively will seek out and perform antidiscriminatory institutional work.

However, there is reason to believe that the racial minorities at the top of the corporate hierarchy will neither racially reform the corporation, nor engage in door-opening activities, for the minorities on the bottom. Indeed, strong incentives exist for minorities to race to the top of the corporation and lift the ladder up behind them when they get there. This Article sets forth the nature of these incentives, reveals how they help to produce particular racial types, and explains why these racial types might not have the racial commitment, or feel institutionally empowered, to lift as they climb.

\section{Prologue}

Success within any large and bureaucratic organization is a function of complicated micro-dynamics. Producing more widgets than one's competitors is not enough. Negotiating the political landscape of the institution is also required. ${ }^{1}$ The more bureaucratic the organization, and the more opaque and political the promotion process, the more important it becomes for employees to perform this negotiation or play this institutional game. Being obsequious to and pleasing the right superiors, cultivating appropriate sources of information, and affiliating oneself with powerful interest groups are but a few forms the negotiation can take. This Article is about the types of racial minorities who are most likely to succeed at playing this political game.

Identifying these racial types is crucial to the project of making the internal environments at large corporations more welcoming to racial minorities. This is because we rest many of our hopes for the racial improvement of these organizations on the successes of the first few generations of minority employees. The notion is that minorities on the top of the corporation will help those on the

1. For two general treatments of workplace dynamics that combine an understanding of both economic and organizational behavior theories, see generally JAMES N. BARON \& DAVID M. KREPS, STRATEgic HUMAN RESOURCES: FraMEWORKS FOR GENERAL MANAGERS (1999); PAUL MILGROM \& JOHN ROBERTS, ECONOMICS, ORgANIZATION, AND MANAGEMENT (1992). The general perspective of melding conventional economics, behavioral economics, and organizational behavior draws from the work of instititutionalists such as James March and Oliver Williamson. See generally JAMES G. MARCH, DECISIONS AND ORGANIZATIONS (1988); JeFFrey PFEFFER, MANAGING WITH POWER: POLITICS AND INFLUENCE IN ORgANIZATIONS (1992); KARL E. WEICK, SENSEMAKING IN ORGANIZATIONS (1995); Oliver E. Williamson, Introduction to ORgANizATION ThEORY: FroM CHESTER BARNARD TO THE PRESENT AND BEYOND 3 (Oliver E. Williamson ed., 1990). 
bottom. The empirical question is whether this is in fact the case. Our preliminary examination of this issue concludes on a pessimistic note. The types of racial minorities most likely to succeed may not be the ones most likely to perform door-opening activities for other minorities. In other words, there is reason to fear that the minorities who race to the top of the corporate ladder will not "lift as they climb."2

2. The expression originated as a slogan of the National Association of Colored Women's clubs. See Kathleen M. Tangenberg, Linking Feminist Social Work and Feminist Theology in Light of Faith-Based Service Initiatives, 18 AFFILIA: J. WOMEN \& SOC. WORK 379, 381 (2003).

The [NACW] clubs were established in 1896 to provide support to African American women and to combat negative racial stereotypes. The slogan adopted by NACW, "Lifting as we climb," was used to refer to the commitments of club members to lift each other socially, economically, and spiritually as their communities suffered the profound effects of racial discrimination.

Id. (citation omitted). It continues to have currency inside and outside the black community. For an indication of its continued usage in the black community, see Bari al-Hakim, Letters to the Editor: UC Regent: A Disgrace to His Race, ThE DAIL Y CALIFORNIAN ONLINE, Jan. 18, 2001, at http://www.dailycal.org/article.php?id=4243 (last visited Oct. 22, 2004) (speaking of University of California Regent Ward Connerly) (on file with the Washington and Lee Law Review). Of Regent Connerly, al-Hakim states:

It astounds me that this man, this black man, has forgotten where he has come from. He has completely neglected the idea that we have in our community to "lift as we climb." Instead, he is kicking as he climbs, kicking those hot on his heels. He is a disgrace to beneficiaries of affirmative action, and as a member of the black community.

Id.; see also Normal K. Jenkins, Welcome to NATIONAL Association of BlaCK ACCOUNTANTS, INC., at http://www.nabainc.org/pages/Home.jsp (last visited Oct. 22, 2004) (identifying the Association's motto as "Lifting As We Climb") (on file with the Washington and Lee Law Review); LIFTING As WE CLIMB, Who We Are, at http://www.liftingasweclimb.org/aboutus.html (last visited Oct. 22, 2004) ("Lifting As We Climb is a non profit organization dedicated to strengthening the African American community ....") (on file with the Washington and Lee Law Review); Alison Bernstein, Remarks at the National Council for Research on Women's 6th Annual Women Who Make a Difference Awards Dinner, at http://www.ncrw.org/interest/ bernstein_remarks.htm (Mar. 11, 2004) (using the expression to describe the deployment of women's power) (on file with the Washington and Lee Law Review); R.J. Grubb, Making Sure the Kids Are All Right: Queerstock Producer and Ladyfest Organizer Doria Roberts Performs at Boston GLASS to Boost Queer Youth, BAY WINDows ONLINE, (Feb. 20, 2003), at http://www.baywindows.com/news/2003/02/20/ Arts/Making.Sure.The.Kids.Are.All.Right-37 5248.shtml (last visited Oct. 22, 2004) (reporting that queer musician Doria Roberts "lives by" the expression: "It's very important that wherever you're going that you take as many people with you [as you can]. It's an important practice.' . . Recently, [Queerstock] expanded its mission to earmark funds and promote awareness for queer youth advocacy agencies around the country.") (on file with the Washington and Lee Law Review); Sue Katz, Community Gathers for Rustin Breakfast, BAY Windows ONLINE, Apr. 10, 2003, at http://www.baywindows. $\mathrm{com} /$ news/2003/04/10/LocalNews/Community.Gathers.For.Rustin.Breakfast-414258.shtml (last visited Oct. 22, 2004) (quoting a speaker at the Bayard Rustin Breakfast using the expression in reference to what the "GLBT pioneers from communities of color" have taught activists) (on file 
In the context of that pessimistic projection, it seems appropriate to remember Jerome Culp and Marilyn Yarborough, both of whom passed from our midst within the past few months. Jerome and Marilyn were among the first racial minorities to gain tenure and acquire institutional power at elite American law schools-Duke and the University of North Carolina, respectively. The two of us were fortunate to have known Jerome and Marilyn as both friends and mentors. Neither one was especially fond of talking about the barriers that they had overcome, but the few stories they told us suggested that those successes came in the face of overwhelming barriers.

This should not surprise us. While the number of people of color on the faculty of American law schools remains dismal, the racial representation picture was even worse when Jerome and Marilyn entered the academy. And so was the institutional culture of law schools: Open hostility towards minorities was not uncommon, and more subtle forms of racial discrimination were rampant. Jerome and Marilyn became law teachers when there were very few courses on race and law and when minority faculty actively were discouraged from, and disciplined for, pursuing a civil rights-oriented scholarly agenda. Indeed, it is precisely this discouragement and discipline that helps to explain why Richard Delgado, one of the nation's most productive and influential critical race theorists, did not begin writing about race until after he received tenure. ${ }^{3}$

with the Washington and Lee Law Review); Phumzile Mlambo-Ngcuka, The Nature of Women's Leadership: A Roundtable Before the Global Summit of Women 2001, at http://www.globewomen.com/ bus_net2/wisdom_exchange.asp (Sept. 15, 2001) (encouraging leaders to "[1]ift as you climb because it is lonely at the top if you are alone") (on file with the Washington and Lee Law Review); Javier Rosado, Latino Students Success Stories: Successful Latino Students!!, at http://www. coedu.usf.edu/zalaquett/ls/lsjavier.html (last visited Oct. 22, 2004) ("I am excited about what the future will bring and in all I do I will be certain to always apply the key lesson I have learned from the Latino Scholarship: 'We must lift as we climb.'") (on file with the Washington and Lee Law Review).

3. See Richard Delgado, The Imperial Scholar: Reflections on a Review of Civil Rights Literature, in CRITICAL RACE ThEORY: THE KeY WRITING THAT FORMED THE MOVEMENT 46 (1995). According to Delgado:

When I began teaching law in the mid-seventies, I was told by a number of wellmeaning senior colleagues to "play things straight" in my scholarship-to establish a reputation as scholar in some mainstream legal area and not to get too caught up in civil rights or other "ethnic subject." Being young, impressionistic, and anxious to succeed, I took their advice to heart and, for the first six years of my career, produced a steady stream of articles, book reviews, and the like impeccably traditional in substance and form. The dangers my friends warned me about were averted; the benefits accrued. Tenure securely in hand, I turned my attention to civil rights law and scholarship.

Id. 
Notwithstanding that neither Jerome nor Marilyn had much help negotiating and responding to the institutional racial pressures they encountered, they managed to succeed and to facilitate the success of other faculty of color. In other words, despite the fact that they themselves had the benefit of few helping hands, they were unfailingly selfless in expending their institutional capital to assist the careers of succeeding generations of minority scholars. Each of them could likely have had even more power and success within the legal academy and their own institutions had they not expended so much of their hard-earned capital on enhancing the opportunities for other minority scholars. Indeed, had they occasionally supported undermining the career of some especially rambunctious minority scholar, their influence within their institutions would have increased immensely.

Yet, what we remember of them is that they were always willing to give and rarely willing to take. And for both it went without saying that there was a racial responsibility on the part of people of color to lift as they climb. III health hit them far too early and robbed too many of us of the opportunity to learn from them. ${ }^{4}$ The two of us owe them a deep debt, not just for the support and encouragement that they provided us individually, but for the examples of selfless behavior that they set. They remain in our hearts and minds. And, we write this Article hopeful that, at least marginally, it captures the normative spirit of their lives.

\section{Table of Contents}

I. Introduction 1650

II. The Benefits We Assume Will Accrue from the First Generation of Minority Successes in the Workplace.

A. Stereotype Negation.

B. Racial Monitoring 1660

C. Racial Accountability 1662 1664

4. Happily, both left their writing; thus we can continue to learn from them and experience their presence. See generally Jerome McCristal Culp, Jr., The Michael Jackson Pill: Equality, Race, and Culture, 92 Mich. L. REv. 2613 (1994); Jerome McCristal Culp, Jr., Toward a Black Legal Scholarship: Race and Original Understandings, 1991 DUKE L.J. 39; Jerome McCristal Culp, Jr., Water Buffalo and Diversity: Naming Names and Reclaiming the Racial Discourse, 26 ConN. L. REv. 209 (1993); Barbara Osborne \& Marilyn V. Yarborough, Pay Equity for Coaches and Athletic Administrations: An Element of Title IX?, 34 U. MICH. J.L. REFORM 231 (2000-2001); Marilyn V. Yarborough, A Sporting Chance: The Intersection of Race and Gender, 38 S. TEX. L. REV. 1029 (1997); Marilyn V. Yarborough, Still Separate and Still Unequal, 36 WM. \& MARY L. REV. 685 (1995). 


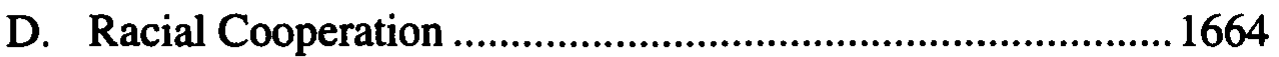

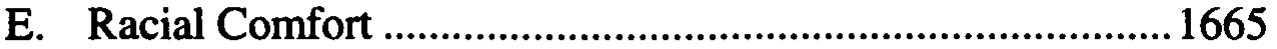

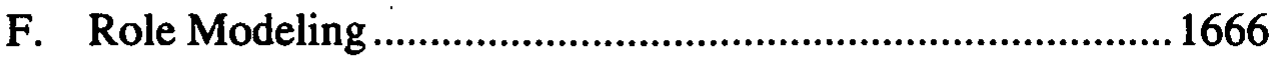

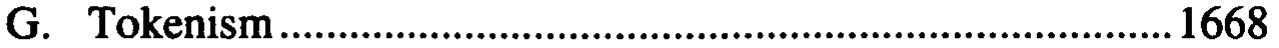

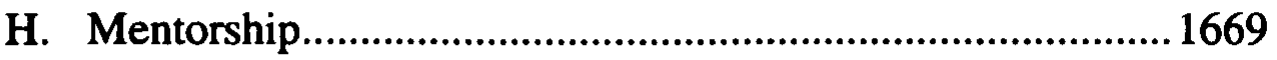

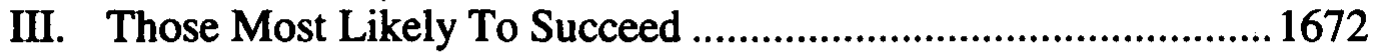

A. Risk-Taking, Luck, and Overconfidence .............................. 1673

B. Team Work and Racial Fit...............................................1675

C. Managing Other Minorities ................................................... 1676

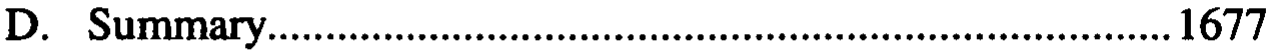

IV. The Likelihood of Ameliorative Tasks Being Performed ............1677

A. Stereotype Negation............................................................1678

1. Racial Group Negation Strategies .................................1678

a. The Difficulties of Direct Intervention...................1678

b. Indirect Intervention...............................................1681

2. Individual Identity Negation Strategies ..........................1682

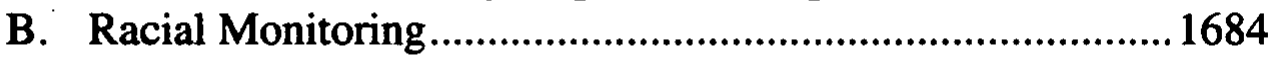

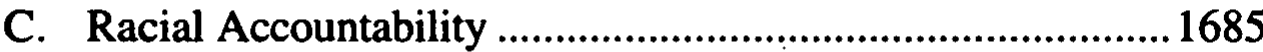

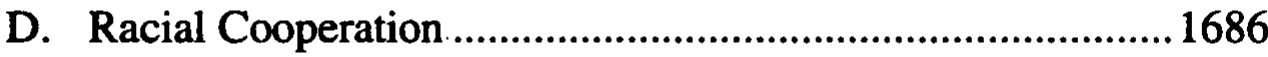

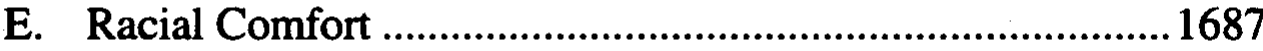

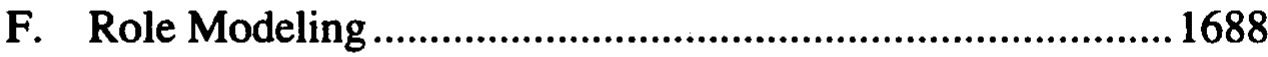

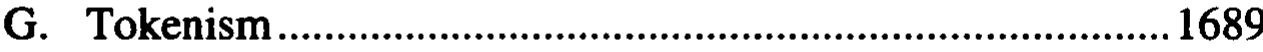

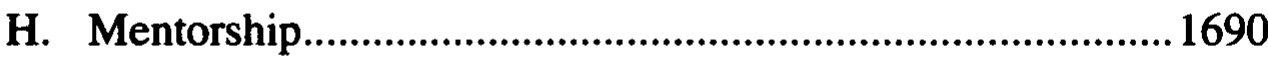

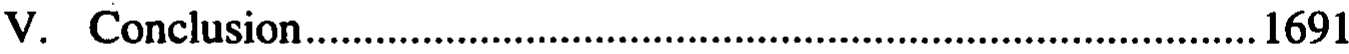

\section{Introduction}

Climbing the stairs of the corporate hierarchy is difficult, no matter how qualified and capable the candidate. Individual corporate officers have to be appeased, powerful interest groups have to be co-opted and made allies, and competitors have to be undermined or eliminated. These skills are essential to corporate success - career advancement-and often simultaneously produce corporate failures-company demise. Precisely how this success-failure dynamic manifests itself is, of course, context-dependent as several scholars have detailed in the recent case of Enron. ${ }^{5}$ Still, the phenomenon is

5. For textured analyses of the Enron scandal, see generally William W. Bratton, Enron and the Dark Side of Shareholder Value, 76 TuL. L. REv. 1275 (2002); Lynne L. Dallas, A 
sufficiently generalizable so that, with respect to the numerous corporate scandals of the past few years, the central question has been: Why do unscrupulous corporate types often win the race to the top of the corporate hierarchy? By and large, two narratives have been articulated to answer that question: the good apple gone bad and the undetected bad seed.

In the good apple gone bad narrative, corporate officers who engage in scandalous behavior are aberrations, not the norm. There is rarely more than one or two of them within any corporation. Significant in this story is the notion that these corporate officers were not always bad-when they were hired they were good. In this narrative, the corporate governance challenge is to prevent the one or two bad apples from destroying the corporation and to figure out what causes good apples to turn bad.

In the undetected bad seed narrative, the corporate officer was never good. He entered the corporation as a bad seed and grew undetected. Precisely how he did so is a mystery. Here, the corporate governance challenge is to develop a screening process that detects and rejects bad seeds and, as a backup, to create an institutional field within which bad seeds will not grow.

Significantly, in each of the foregoing narratives, the conduct of the corporate officer figure is nonnormative. In other words, under both accounts-the good apple gone bad and the undetected bad seed-the CEOs and CFOs at Tyco, Worldcom, Enron, Adelphia, Healthsouth, and many others engaged in countercultural corporate behavior. Neither their corporate misconduct nor their corporate rise should have occurred. In both narratives the corporation appears as a victim of bad corporate conduct-conduct that each narrative disaggregates from and represents as oppositional to normative corporate culture. In part, as a result of these narratives and the twin notions within them that bad corporate conduct is (a) rare and (b) seldom rewarded with promotion, the voluminous literature on corporate leadership focuses on the positive traits of corporate executives, such as self-awareness, motivation, empathy, the willingness to listen to criticism, the capacity to compromise, and the ability to inspire. ${ }^{6}$ Less attention has been paid to what one might call the "dark side" of leadership.?

Preliminary Inquiry into the Responsibility of Corporations and Their Officers and Directors for Corporate Climate: The Psychology of Enron's Demise, 35 RUTGERs L.J. 1 (2003); Donald C. Langevoort, The Organizational Psychology of Hyper-Competition: Corporate Irresponsibility and the Lessons of Enron, 70 GEO. WASH. L. REV. 968 (2002); Marleen A. O'Connor, The Enron Board: The Perils of Groupthink, 71 U. CIN. L. REv. 1233 (2001). For a cautionary note on the lessons that can and cannot be drawn from examining only a handful of corporate debacles, see generally Gregory Mitchell, Case Studies, Counterfactuals, and Causal Explanations, 152 U. PA. L. REV. 1517 (2004).

6. These traits and others are discussed at length in a recent issue of the Harvard 
Yet in all of the recent scandals, some organization consciously chose to promote individuals who were likely to race to the top of the corporation via lies and obfuscation. And that leads one to ask whether there is something in the nature of corporate promotion processes that rewards problematic personality characteristics, ${ }^{8}$ for individual corporate officers do not

Business Review that reprinted some of its classic articles on leadership. See, e.g., Diane L. Coutu, Putting Leaders on the Couch: A Conversation with Manfred F.R. Kets de Vries, HARV. BUS. REV., Jan. 2004, at 64 (interviewing analytical scholar regarding the profile of successful leaders); Daniel Goleman, What Makes a Leader?, HARV. BuS. REV., Jan. 2004, at 82 (discussing the components of "emotional intelligence" and applying the concept to businesses); W.C.H. Prentice, Understanding Leadership, HARV. BUS. REV., Jan. 2004, at 102 (analyzing leadership and what makes a successful leader); Abraham Zaleznik, Managers and Leaders: Are They Different?, HARV. BuS. REV., Jan. 2004, at 74 (observing the difference between business leaders and managers and the environment in which each group succeeds). More broadly, in this feel-good vein about leadership, see generally WARREN BENNIS \& BURT NANUS, LEADERS: THE STRATEgIES FOR TAKING CHARGE (1985); WARREN BENNIS, ON BECOMING A LEADER (1989); JAMES MACGREGOR BURNS, LEADERSHIP (1978); JAY A. CONGER \& BETH BENJAMIN, BUILDING LEADERS: HOW SUCCESSFUL COMPANIES DEVELOP THE NEXT GENERATION (1999); JOHN P. KOTTER, A FORCE FOR CHANGE: HOW LEADERSHIP DIFFERS FROM MANAGEMENT (1990); ThOMAS J. PETERS \& Robert H. WATERMAN, JR., IN SEARCh OF EXCELlENCE: LesSONS FROM AMERICA's BEST-RUN COMPANIES (1982).

7. See Barbara Kellerman, Leadership-Warts and All, HARV. BuS. REV., Jan. 2004, at 40 (recognizing prior literature identifying leaders as good people and how these views were distorted). See generally SydNEY FINKELSTEIN, Why SMART EXECUTIVES FAIL: AND WHAT You CAN LEARN FROM THEIR MISTAKES (2003) (researching the causes of business failure and the leadership involved); BARBARA KELLERMAN, BAD LEADERSHIP: WHAT IT Is, HOW IT HAPPENS, WHY IT MATTERS (2004) (analyzing the harms done by leadership and how to reduce them). For writing along these lines in the popular press, see Holman W. Jenkins, Jr., How Could They Have Done It?, WALl ST. J., Aug. 28, 2003, at A15 (concluding that those in charge of firms such as Enron, Tyco, and Worldcom overestimated their ability and underestimated the risk of being detected).

8. Some corporate law scholars have suggested that the internal promotion dynamics in these firms were such that they rewarded the kinds of behavior and the types of individuals who exhibited that behavior that was likely to lead to disasters. See supra note 5 (citing articles). For example, Langevoort writes the following of the Enron culture:

The [Enron] culture quickly identified itself as special and uniquely competent, believing that special skill rather than luck (or just being first) was responsible for the early victories. That self-definition then set a standard for how up-and-coming people acted out their roles: Enron was a place for winners. With this-and the stock market's positive feedback - the company's aspiration level rose.

This aspiration level required a high level of risk-taking by the firm, though like many egocentric people, key decision-makers were probably overconfident in their ability to manage these risks, and thus underestimated them.... Enron harshly penalized the laggards at the firm, which, on average, tends to lead to herding behavior (risk aversion). To counteract this, the company had to magnify the reward structure considerably for those who ended up as stellar performers-a winner-take-all kind of tournament.

Presumably this worked, and key people gradually placed more and more risky bets 
systematically lie, cheat, and steal on their own. Sub-organizations within the corporation support them-that is, protect and promote them. This raises at least two questions.

First, what are the institutional incentives for the supply of this support? And second, what types of individuals are most likely to benefit from it? Though both questions interest us, our primary concern is with the second. It permits us to engage directly the central theme of this conference, namely, the relationship between business law and critical race theory (CRT). ${ }^{9}$ Our aim is not to articulate a general relationship but rather to combine insights from CRT and corporate governance theory to tell a tentative story about racial types and corporate advancement. ${ }^{10}$ More particularly, our project is to shed

in a variety of fields, increasingly outside of the firm's core competence. And predictably, many of these turned bad.... In sum-and in previous work I've called this the "optimism-commitment whipsaw"-their overconfidence commits them to a high-risk strategy; once committed to it, they are trapped.

Langevoort, supra note 5, at 973-74. David Skeel makes a somewhat different argument in that he attributes primary blame not to the internal labor markets of these firms, but to the external labor market that had become highly volatile-that is, employees no longer stayed with a single firm for any meaningful length of time but instead jumped from job to job. See generally DAVID A. SKEEL, JR., ICARUS IN THE BOARDROOM: THE FUNDAMENTAL FlaWS IN CORPORATE AMERICA AND WHERE THEY CAME FROM (forthcoming 2004) (discussing the development of current corporate structures and the role of charismatic leaders).

9. For collections of the leading CRT articles, see generally CRITCAL RACE FEMINISM: A READER 223-86 (Adrien Katherine Wing ed., 1997); CrITICAL RACE THEORY: CROSSROADS, Directions, AND A NEW CRITICAL RACE THEORY (Francisco Valdes et al. eds., 2002); CRITICAL RACE THEORY: THE CUTTING EDGE (Richard Delgado \& Jean Stefancic eds., 2d ed. 2000); Critical Race Theory: The Key Writings that Formed the Movement (Kimberlé Crenshaw et al. eds., 1995).

10. The insight that scholars concerned about equality should focus their lens on the business law area is not new. For recent articles in this direction, see generally Leonard $M$. Baynes, Falling Through the Cracks: Race and Corporate Law Firms, 77 ST. JOHN's L. ReV. 785 (2003); Emily M.S. Houh, Critical Interventions: Toward an Expansive Equality Approach to the Doctrine of Good Faith in Contract Law, 88 CORNELL L. REV. 1025 (2003); Thomas W. Joo, A Trip Through the Maze of "Corporate Democracy", 77 ST. JOHN's L. REV. 735 (2003); Steven A. Ramirez, The New Cultural Diversity and Title VII, 6 MiCH. J. RACE \& L. 127 (2000); Cheryl L. Wade, Comparisons Between Enron and Other Types of Corporate Misconduct: Compliance with Law and Ethical Decision Making as the Best Form of Public Relations, 1 SEATTLE J. FOR SOC. JUST. 97 (2002); Cheryl L. Wade, Corporate Governance as Corporate Social Responsibility: Empathy and Race Discrimination, 76 TUL. L. REV. 1461 (2002). Two recent CRT casebooks move away from the traditional CRT focus on civil rights and focus instead on economic justice. See generally DOROTHY A. BROWN, CRITICAL RACE Theory: Cases, Materials, and Problems (2003); EMma Coleman Jordan \& ANGela DAVIS, When Markets FaIl: A CRITICAL PERSPECTIVE ON ECONOMIC JUSTICE (forthcoming 2005). Ventures such as those mentioned above, however, have been few and far between and, for the most part, not greeted with great enthusiasm by those who dominate these fields. By putting together this symposium and encouraging us to think collectively about these issues, Dorothy Brown is ensuring follow up on these initial attempts. 
light on how people of color negotiate the promotional processes at large corporations, to identify the types of people of color who are likely to rise to the top, and to theorize about whether and to what extent these people will perform door-opening for other nonwhites. Our central claim is that the corporation both selects for and produces racial types to win multiround promotion tournaments. These racial types, we contend, are unlikely to be invested in facilitating the promotion of other nonwhites. We should be clear to point out that this lack of investment does not derive from a normative commitment on the part of senior people of color to disidentify with other racial minorities. The disinvestment exists because of the institutional rewards of racial disidentification and institutional costs of perceived racial group association.

The corporate governance literature that gives legs to our story is represented most clearly by the work of Don Langevoort." ${ }^{11}$ Of particular interest to us is Langevoort's engagement of the following question: What corporate type is most likely to defeat its competitors in the race for promotion? Note that the question specifically focuses on corporate type. Put another way, the inquiry is less about widget-making capacity and more about corporate personality. $^{12}$ Drawing heavily from the management, psychology, and institutional economics literature, Langevoort sets forth the identity traits that corporate leaders are most likely to reward in multiround promotion tournaments ("probationary crucibles," he calls them ${ }^{13}$ ): overconfidence, a

11. Two examples of this literature are Donald C. Langevoort, Overcoming Resistance to Diversity in the Executive Suite: Grease, Grit and the Corporate Promotion Tournament, 61 WASH. \& LEE L. REV. 1613 (2004) [hereinafter Langevoort, Grease \& Grit] and Donald C. Langevoort, Resetting the Corporate Thermostat: Lessons from the Recent Financial Scandals About Self-Deception, Deceiving Others and the Design of Internal Controls, 95 GEO. L.J. (forthcoming 2005) [hereinafter Langevoort, Resetting the Corporate Thermostat] (manuscript on file with Washington and Lee Law Review).

12. The widget-making capacity and corporate personality distinction is important. The personality question decenters the importance of widget-making skills and links corporate advancement to institutional politics or to the capacity to build coalitions and undermine competitors. See Langevoort, Resetting the Corporate Thermostat, supra note 11 (manuscript at 4-9) (discussing how corporate personality has played and will continue to play a role in the corporate setting). See generally Daniel C. Feldman \& Barton A. Weitz, From the Invisible Hand to the Glad Hand: Understanding a Careerist Orientation to Work, 30 HUM. RESOURCE MGMT. J. 237 (1991); Langevoort, Grease and Grit, supra note 11. An article on leadership in The Economist recently made this point in humorous fashion by pointing to research on chimpanzees. See Creating Leaders: Charisma Helps, but It Is Only a Beginning, ECONOMIST, Oct. 25, 2003, at 7 (pointing to Frans de Waal's book, ChIMPANZEE PolTtics: POWER AND SEX AMONG APES (rev. ed. 1989), and observing that "battles [for leadership positions] ... are mainly about the ability to build a coalition of supporters and to outwit rivals, rather than about size and strength").

13. See Langevoort, Grease and Grit, supra note 11, at 1623 (citing Robert Jackall, 
willingness to take high risks, and a high degree of ethical plasticity. ${ }^{14} \mathrm{We}$ refer to these traits collectively as "advancement traits." Langevoort suggests

MORAL MAZES 68 (1988), from whom he takes the term "probationary crucibles").

14. Id. Langevoort's insights on risk-taking and overoptimism rest on a large body of research in a variety of areas, including the following: J. EDWARD RUSSO \& PAUL J.H. SCHOEMAKER, DECISION TRAPS: TEN BARRIERS TO BRILLIANT DECISION-MAKING AND How to OVERCOME THEM (Fireside 1990) (1989); MARTIN E.P. SELIGMAN, LEARNED OPTIMISM (1991); Daniel Kahneman \& Dan Lovallo, Timid Choices and Bold Forecasts: A Cognitive Perspective on Risk Taking, 39 MgMT. SCI. 17 (1993); SIMON GeRVAIS ET AL., OVERCONFIDENCE, INVESTMENT POLICY, AND EXECUTIVE STOCK OPTIONS (Rodney L. White Center for Fin. Research, Working Paper No. 15-02), at http://papers.ssrn.com/so13/papers.cfm?abstract= 361200 (2003) (on file with the Washington and Lee Law Review). On the theoretical side, see generally Roland Bénabou \& Jean Tirole, Self-Confidence and Personal Motivation, 117 Q. J. ECON. 871 (2002); Anand Mohan Goel \& Anjan V. Thakor, Rationality, Overconfidence, and Leadership (unpublished draft), at http://papers. ssm.com/so13/papers.cfm?abstract_id=244999 (Sept. 2000) (on file with the Washington and Lee Law Review).

On ethical plasticity, Langevoort's insights diverge from the assumption that it is those who cooperate best and are the most loyal who will be most likely to be rewarded in a promotion system that values production in teams. See generally Robert Cooter \& Melvin A. Eisenberg, Faimess, Character, and Efficiency in Firms, 149 U. PA. L. REV. 1717 (2001) (making the point that traditional economics puts too much emphasis on opportunism and that firms are likely to select those who are most likely to demonstrate more altruistic tendencies); Ram T.S. Ramakrishnan \& Anjan V. Thakor, Cooperation Versus Competition in Agency, 7 J.L. ECON. \& ORG. 248 (1991) (researching the choice and effects of cooperation versus competition among agents in conglomerate mergers and within organizational incentive-based systems). That makes sense, Langevoort says, except that the evaluation of who is the best cooperator and who is most loyal takes the form of a competition. The person who will be promoted, therefore, will be the one who is best able to outperform his colleagues in demonstrating loyalty and cooperation, and that person is not always the person who is, in fact, most loyal and cooperative. Instead, in many settings it will be someone who can appear to be loyal while actually being opportunistic; someone with a chameleon-like personality. Langevoort, Grease and Grit, supra note 11, at 1620-25; see also Martin Kilduff \& David Day, Do Chameleons Get Ahead? The Effects of Self-Monitoring on Managerial Careers, 37 ACAD. MGMT. J. 1047, 1048 (1994) (observing that evidence indicates that an individual's success in an organization can be increased by controlling impressions). What Langevoort is describing is a kind of hyperrationality in that he rejects the simple prediction that just because organizations desire employees who are loyal, fair, and team oriented, they will end up hiring those people. Instead, because employees will modify their behavior to appear to be what the organization desires, the organization is likely to hire those who can best appear to have those characteristics. See Samuel Bowles et al., The Determinants of Earnings: A Behavioral Approach, 39 J. Econ. LITERATURE 1137, 1161-62 (2001) (examining the role of incentive-enhancing personal characteristics on earnings); Myron Gable \& Frank Dangello, Locus of Control, Machiavellianism and Managerial Job Performance, 128 J. PSYCHOL. 599, 600 (1994) (noting that managers with manipulative Machiavellian tendencies are more likely to advance).

The idea of a "chameleon-like" personality has a close link to the notions of "high self monitoring" and "code switching" that are more commonly discussed in the academic literature on organizational behavior and social psychology. People who can shape their identity to the needs of an organizational context are found to be more likely to succeed to leadership positions and to fill key structural holes in the organization. See generally Robert J. Ellis et al., Self- 
that to the extent that the people at the top of the corporation-mostly white men-got there by exhibiting advancement traits, they are less likely to comply with a variety of regulatory mandates, including those relating to racial diversity. ${ }^{15}$

But what if those at the top of the corporate hierarchy are people of color? What types of racial minorities are they likely to be? Only a decade or two

Monitoring and Leadership Emergence in Groups, 14 PERSONALITY \& SOC. PSYCHOL. BULL. 681 (1988); Ajay Mehra et al., The Social Networks of High and Low Self-Monitors: Implications for Workplace Performance, 46 ADMIN. SCI. Q. 121 (2001); Stephen J. Zaccaro et al., Leadership and Social Intelligence: Linking Social Perspectiveness and Behavioral Flexibility to Leader Effectiveness, 2 LEADERSHIP Q. 317 (1991); Stephen J. Zaccaro et al., SelfMonitoring and Trait-Based Variance in Leadership: An Investigation of Leader Flexibility Across Multiple Group Situations, 76 J. APPLIED PSYCHOL. 308 (1991). On the relationship between the terms of "self monitoring" and "code switching," see William E. Cross \& Linda Strauss, The Everyday Functions of African American Identity, in PREJUDICE: THE TARGET'S PERSPECTIVE 267, 273-76 (Janet K. Swim \& Charles Stangor eds., 1998).

15. Writing in a similar vein as Langevoort, David Skeel, another participant in this Symposium, emphasizes the tendency of high-velocity labor markets to overvalue leadership characteristics such as charisma. See SKEEL, supra note 8, at 7 ("Corporate culture continues to reward managers who are willing to take risks and don't second guess the genius of the decisions they make."). Like Langevoort, Skeel draws heavily from the management literature. On the tendency of certain types of business settings to excessively reward certain traitscharisma-and psychological types-narcissists, see generally RAKESH KHURANA, SEARCHING FOR A CORPORATE SAVIOR, THE IRRATIONAL QUEST FOR CHARISMATIC CEOS (2002); Michael Macoby, Narcissistic Leaders: The Incredible Pros, the Inevitable Cons, HARV. Bus. REV., Jan.-Feb. 2000, at 68. For more on the problems that are likely to result from the selection of these individuals for advancement, see generally Lisa M. Penney \& Paul E. Spector, Narcissism and the Counterproductive Work Behavior: Do Bigger Egos Mean Bigger Problems?, 10 INT'L J. SELECTION \& ASSESSMENT 126 (2002). Others suggest that organizations going through internal turbulence can sometimes have environments that are conducive to the success of psychopaths. See Paul Babiak, When Psychopaths Go to Work: A Case Study of an Industrial Psychopath, 44 APPLIED PSYCHOL. 171, 176 (1995) (suggesting that "in the chaotic business world of 'flattening', 'right-sizing', mergers, and acquisitions, a large number of transitional organisations [sic] exist, offering variety and stimulus without the controls found in more stable organisations [sic], and may offer an environment conducive to psychopathic manipulation"). For other discussions in this vein, see generally Paul Babiak, Psychopathic Manipulation at Work, in THE CLINICAL AND FORENSIC ASSESSMENT OF PSYCHOPATHY: A PRACTITIONER's GUIDE 287 (Carl B. Gacono ed., 2000); Sigrid B. Gustafson \& Darren R. Ritzer, The Dark Side of Normal: A Psychopathy-Linked Pattern Called Aberrant Self-Promotion, 9 EUR. J. PERSONALITY 147 (1995). These discussions have even made their way into the popular press. See Hilary Freeman, Psycho Bosses on the Loose: Are You in Their Line of Fire?, GuARDIAN UNLIMITED, Mar. 10, 2001, at http://www.guardian.co.uk/Archive/Article/0,4273,4149556, 00.html (last visited Oct. 22, 2004) (describing research in the area by scholars such as Paul Babiak and Robert Hare) (on file with the Washington and Lee Law Review); Simon English, Psycho at the Top?, THE AGE, Oct. 29, 2002, at http://www.theage.com.au/articles/2002/ 10/281035683360087.html? oneclick=true/ (last visited Oct. 22, 2004) (same) (on file with Washington and Lee Law Review). For the purpose of this Article, we focus on the multiround tournament structure that Langevoort describes. 
ago, this would have been a pointless inquiry; there were almost no minorities who successfully traveled to the top of the corporate hierarchy. But today, while the numbers are decidedly small, people of color are reaching the top, and others are on their way. For the most part, CRT has addressed the issue of minority presence in the corporate context with arguments about underrepresentation and employment discrimination. ${ }^{16}$ While these arguments are important, there is another intellectual use for CRT. ${ }^{17}$ The literature can help us conceive of the corporation itself as a racial body-a body that produces and makes promotional decisions based on racial types. ${ }^{18}$ By racial

16. See generally Paulette M. Caldwell, $A$ Hair Piece: Perspectives on the Intersection of Race and Gender, 1991 DUKE L.J. 365; Kimberle Crenshaw, Demarginalizing the Intersection of Race and Sex: A Black Feminist Critique of Antidiscrimination Doctrine, Feminist Theory and Antiracist Policies, 1989 U. ChI. Legal F. 139; Mari J. Matsuda, Voices of America: Accent, Antidiscrimination Law, and a Jurisprudence for the Last Reconstruction, 100 Y ALE L.J. 1329 (1991).

17. Part of the intellectual project of CRT is to think critically about ostensibly neutral institutions such as law. See generally Kimberlè Williams Crenshaw, Race, Reform, and Retrenchment: Transformation and Legitimation in Antidiscrimination Law, 101 HARV. L. REV. 1331 (1988). In conducting this inquiry, thus far CRT scholars primarily have focused on those areas of law where racial issues are directly implicated, like the following: equal protection law, (Cheryl I. Harris, Equal Treatment and the Reproduction of Inequality, 69 FORDHAM L. REV. 1753 (2001) (discussing the Supreme Court's interpretation and application of equal treatment as equal protection and the effect on inequality)), election law, (Spencer Overton, But Some Are More Equal: Race, Exclusion, and Campaign Finance, 80 TEX. L. REV. 987 (2002) (utilizing race to analyze campaign finance laws)), criminal law, (Paul D. Butler, Race-Based Jury Nullification: Case-in-Chief, 30 J. MARSHALL L.REV. 911 (1997) (asserting that selective jury nullification is a way to alter the unjust effect that the American criminal justice system has on African Americans)), immigration law, (Leti Volpp, Court-Stripping and Class-Wide Relief: A Response to Judicial Review in Immigration Cases After AADC, 14 GEO. IMMIGR. L.J. 463 (2000) (discussing Immigration and Nationality Act $\$ 242(f)$ in detail)), and Fourth Amendment law, (Devon W. Carbado, (E)racing the Fourth Amendment, 100 MicH. L. REV. 946 (2002) (exposing non-neutral investments of Fourth Amendment law)); Angela J. Davis, Race, Cops, and Traffic Stops, 51 U. MiAMI L. ReV. 425 (1997) (same)).

Racial disadvantage and bias may be embedded in other areas of law as well, which, of course, is Dorothy Brown's rationale for organizing this Symposium-to turn the CRT lens on the business arena. Arguably, the area of law that most directly implicates economic power is business law. To the extent that one is interested in revealing hidden biases that translate into economic disadvantage, a critical inquiry into this area is vital. For example, consider a new bankruptcy reform policy that is meant to further economic responsibility by restricting the ability of individuals to file personal bankruptcy. A CRT inquiry may reveal that this new legislation is driven by the interest of certain large credit card companies who lend primarily to low income families at exorbitant interest rates with the hope that these families will not be able to escape the debt trap. On the flip side, it may be that some new legislation to make corporate bankruptcy easier transfers wealth away from minority groups because it disproportionately benefits the managerial class, which is likely to be predominantly white and male.

18. This inquiry could broaden the context in which CRT scholars make claims about the social construction of race. See generally Ian F. Haney Lopez, The Social Construction of 
type we do not mean the standard racial categories-black, white, Asian, Latina or Latino, and Native American. We mean, roughly, self-representations of nonwhite identity that can be interpreted either as racially palatable or racially salient. A person is racially palatable if she is perceived to be peripherally or unstereotypically nonwhite; she is racially salient if she is perceived to be centrally or stereotypically nonwhite.

At least two reasons exist for paying attention to the corporation as a racial body that selects for and produces racial types. The first relates to what we have previously called the "diversity constraint."19 Large corporations are under some public pressure to racially diversify their management ranks. Thus, there is a disincentive for them to make promotional decisions that result in zero people of color at the top. Corporate racism, in this sense, is often designed to achieve partial, and not total, exclusion. In other words, the corporation will hire and promote some nonwhites-those it perceives to be, and those it perceives have the capacity to become, racially palatable. Because racially palatable nonwhites do not enter the corporation fully formed (they are developed by corporate culture), an examination of the corporation as a racial body can help to identify the parameters of this developmental process and to articulate the content of the character of the racial types this process produces. ${ }^{20}$

Another reason exists for conceiving of the corporation as an identityproducing racial body. Those of us who are cautiously optimistic about the advancement of racial minorities in high-level workplaces rest some of our hope on the door-opening effects of first generation successes. ${ }^{21}$ The thinking

Race: Some Observations on Illusion, Fabrication, and Choice, 29 HARV.C.R.-C.L. L. REV. 1 (1994).

19. Devon W. Carbado \& Mitu Gulati, The Law and Economics of Critical Race Theory, 112 YALE L.J. 1757, 1793 (2003) (book review).

20. $C f$. Shelby Steele, The Content Of OUR Character: A New Vision of Race in AMERICA (1990). The "critical" perspective in all of this is in realizing that those in power at these corporate organizations-that is, those same organizations that are publicly espousing their commitment to diversity-are often white men. The shape that diversity takes, therefore, will be a function of what those white men want. On the observation that any understanding of diversity initiatives needs to consider extant power dynamics, see Erica Gabrielle Foldy, 'Managing' Diversity: Identity and Power in Organizations, in GENDER, IDENTITY AND THE Culture OF Organizations 92, 94 (liris Aaltio \& Albert J. Mills eds., 2002).

21. The classic reference on this hope is to W.E.B. DuBois's concept of the "talented tenth," the elite in the black community, whom he hoped would do the work of pulling up the less fortunate others. W.E.B. DuBois, The Talented Tenth, in THE NEGRO PrOBLEM: A SERIES OF ARTICLES BY REPRESENTATIVE AMERICAN NEGROES OF TODAY (Booker T. Washington ed., 1903). At the time, DuBois's ideas about the importance of the success of the black elites to the successes of the community as a whole stood in contrast to those of Booker $T$. Washington, who instead emphasized the need to focus on the advancement of those in the working class. JoY 
is that the successes of the first generation of racial minorities will, among other things, reduce negative stereotyping, create better mentorship opportunities, and enhance internal accountability on racial issues. However, the racial types that corporations help produce ${ }^{22}$ to win multiround promotion tournaments might not be invested in the success of other nonwhites; put another way, they might not negate stereotypes, provide mentorship, or increase racial accountability. The more we depend on the efforts of the first generation to engage in door-opening activities-or, at least, not to perform door-closing activities - to ensure greater success for later generations, the more important it is for us to examine what types of racial minorities are likely to succeed in corporate environments and the role of the corporation in producing those racial types.

The remainder of this Article proceeds as follows. Part II sets forth eight ways in which the initial successes of people of color in a corporate context can ameliorate discrimination. We call this dynamic the "racial trickle down effect"; the benefits of having a racial minority at the top will trickle down to those at the bottom. ${ }^{23}$ Part III constructs a stylized model of the promotion process as it applies to minorities. Our aim here is to identify the types of minorities who are most likely to race to the top of the corporation. Part IV then raises the question of whether and to what extent these racial types will perform the discrimination-ameliorative functions outlined in Part II. Part V concludes with a discussion of the implications of our argument for antidiscrimination law.

\section{The Benefits We Assume Will Accrue from the First Generation of Minority Successes in the Workplace}

This Part sets forth a set of benefits that theoretically flow from first generation nonwhite corporate successes: stereotype negation, racial monitoring, racial accountability, racial cooperation, a reduction in racial comfort work and the burdens of tokenism, positive role modeling, and

JAMES, TRANSCENDING THE TALENTED TENTH: BlaCk LEADERS AND AMERICAN INTELLECTUALS 22 (1997). In later years, with his support from the black middle class having largely dissipated and most of his support coming from the working class, DuBois himself famously lost much of his hope regarding the elites. W.E.B. DuBoIs, IN BATTLE FOR PEACE 173-74 (1952).

22. Our claim is not that corporations do all of the racial production work. Instead, the claim is that corporations play a role in producing racial types.

23. Cf. Devon W. Carbado, Race to the Bottom, 49 UCLA L. Rev. 1283 (2002) (exploring the difficulties of identifying and managing racial groups at the bottom). 
mentoring-collectively, the trickle down benefits. Though each of these benefits are interrelated, for heuristic purposes, we discuss them separately.

\section{A. Stereotype Negation}

Because most extant discrimination is a function of malleable stereotypes and not explicit animus, ${ }^{24}$ formulating and implementing mechanisms to negate those stereotypes is a crucial antiracist project. ${ }^{25}$ Arguably, senior minority corporate successes operate as a stereotype negating mechanism to the extent that they experience less stereotype threat and greater autonomy. The theory is this: The simple fact of minority success in the corporate promotion tournament will undermine, if not completely disrupt, negative racial stereotypes about work ethic and competence. ${ }^{26}$ If Johnny, who is black

24. This has been one of the most consistent criticisms of the Supreme Court's conceptualization of racism as a problem of conscious intentionality. See Washington v. Davis, 426 U.S. 229, 239-40 (1976) (holding that to establish an equal protection claim, the plaintiff must prove intentional racial decisionmaking on the part of the state); Alan Freeman, Racism, Rights and the Quest for Equality of Opportunity: A Critical Legal Essay, 23 HARV. C.R.-C.L. L. REV. 295, 308 (1988) (stating that the Court's decision in Washington v. Davis was based on the "fantasy" that "racism was an individualistic problem located through careful inquiries into issues such as 'causation' or 'intent'"); Charles R. Lawrence III, "Justice" or "Just Us": Racism and the Role of Ideology, 35 STAN. L. REV. 831, 848-50 (1983) (book review) (arguing that the intent requirement in Washington $v$. Davis prohibits antidiscrimination law from dealing with decisionmaking that maintains existing discriminatory conditions). See generally Linda Hamilton Krieger, The Content of Our Categories: A Cognitive Bias Approach to Discrimination and Equal Employment Opportunity, 47 STAN. L. REV. 1161 (1995) (arguing that biased employment practices often result from categorization-based judgment errors and not from intentional discrimination); Charles R. Lawrence III, The Id, the Ego, and Equal Protection: Reckoning with Unconscious Racism, 39 STAN. L. REV. 317 (1987) [hereinafter Lawrence, The Id] (arguing that discriminatory decisionmaking is usually caused by unconscious beliefs, attitudes, and ideas about race).

25. But see generally IAN AYRes, Pervasive PreJudice?: UnCONVENTIONAL EVIDENCE of RACE AND GENDER DISCRIMINATION (2001) (suggesting that intentional racial discrimination remains a very real social problem and is far more pervasive than we think).

26. The value of this stereotype negation effect is often given as a reason for why affirmative action should be abolished, the theory being that the presence of affirmative action muddies the unambiguous signal of merit that minority success would otherwise provide to all concerned. See, e.g., Stylianos-Ioannis G. Koutnatzis, Affirmative Action in Education: The Trust and Honesty Perspective, 7 TEX. F. ON C.L. \& C.R. 187, 251-54 (2002) (discussing stereotype-based objections to affirmative action); R.A. Lenhardt, Understanding the Mark: Race, Stigma, and Equality in Context, 79 N.Y.U. L. REv. 803, 906 n.490 (2004) ("[T]he durable and demeaning stereotype of black people as unable to compete with white ones is reinforced by advocates of certain forms of affirmative action." (quoting STEPHEN L. CARTER, Reflections of AN AfFirmative ACTION BABY 49-50 (1991))); Jed Rubenfeld, The AntiAntidiscrimination Agenda, 111 Y ALE L.J. 1141, 1173 (2002) ("Racial preferences, however well-intentioned, have poisonous consequences for the very minority groups they are intended 
and male, makes his way to the top of the corporate hierarchy, the theory goes, his success performs both an individual and a group signification-namely, Johnny has the capacity and the commitment to lead a corporation and so do other black men. ${ }^{27}$ The combined effect of both significations is to open up institutional space for the corporation to promote junior black men.

There is another more subtle stereotype negation dynamic at work as well. According to the emerging literature on stereotype threat, people of color under-perform when they perceive the risk that their performance will confirm negative racial stereotypes. ${ }^{28}$ The presence of successful people could reduce this threat in at least two ways. First, junior people of color could conclude from the presence of successful people of color that the corporation is racially tolerant and, more particularly, that the corporate culture is not corrupted by negative racial stereotypes. There is no "threat in the air." ${ }^{29}$ Second, the success of senior people of color could suggest to the juniors that corporate leaders do not interpret the mistakes of nonwhites to be racially predetermined-that is to say, as a confirmation of existing racial

to benefit."). Supporters of affirmative action counter that affirmative action ensures the representation of minorities in predominantly white corporate environments, and this presence sends a message that minorities belong. See Gabriel J. Chin et al., Beyond Self-Interest: Asian Pacific Americans Toward a Community of Justice, a Policy Analysis of Affirmative Action, 4 ASIAN PAC. AM. L.J. 129, 134 (1996) ("Affirmative action also moderates outdated stereotypes by helping racial minorities achieve non-stereotypical positions of leadership and status."); Cynthia L. Estlund, The Workplace in a Racially Diverse Society: Preliminary Thoughts on the Role of Labor and Employment Law, 1 U. PA. J. LAB. \& EMP. L. 49, 65 n.61 (1998) ("But the contact theory research provides at least some significant data to suggest that, on balance, workplace integration, which is certainly partly a result of affirmative action efforts, tends to foster interracial understanding and reduce hostility and negative stereotypes."); Lenhardt, supra, at 915 ("But [the contrary view] of the future is greatly contradicted by the history of affirmative action to date. Studies demonstrate that, with affirmative action, racial minorities are better represented in areas such as medicine, law, and business than they ever have been."). For our purposes, it is enough to note that both sides of the debate recognize the importance of stereotype negation in eliminating contemporary discrimination.

27. Because racial stereotypes often have gender specificity, Johnny's success would not necessarily send a strong signal about the capacity for black women to succeed in that corporate environment. See generally Crenshaw, supra note 16 (articulating the concept of intersectionality to suggest, among other things, that race and gender intersect to affect black women's and black men's vulnerability to discrimination differently).

28. For classic works on the subject, see generally Claude M. Steele \& Joshua Aronson, Stereotype Threat and the Intellectual Test Performance of African Americans, $69 \mathrm{~J}$. PERSONALITY \& SOC. PSYCHOL. 797 (1995), and Joshua Aronson et al., Stereotype Threat and the Academic Underperformance of Minorities and Women, in PREJUDICE: THE TARGET'S PERSPECTIVE 83 (Janet K. Swim \& Charles Stangor eds., 1998).

29. The reference is to Claude M. Steele, A Threat in the Air: How Stereotypes Shape Intellectual Identity and Performance, 52 AM. PSYCHOL. 613 (1997). 
stereotypes. ${ }^{30}$ To the extent that junior people of color respond to the success of seniors in either or both of the foregoing ways, they will likely experience less of a stereotype threat and greater workplace autonomy. Moreover, they are likely to perform their jobs more effectively. ${ }^{31}$

\section{B. Racial Monitoring}

The presence of minorities at the upper echelons of the corporate hierarchy, even in limited numbers, produces racial monitoring. ${ }^{32}$ To appreciate how, imagine a law firm that has been asked to represent a conservative organization in its effort to strike down affirmative action. The mere presence of some black partners on that firm's executive committee, which decides which cases to take, produces at least two monitoring effects-a discourse effect and an outcome effect. At the most basic level, white members of the executive committee will engage the issue of whether to take the case with the awareness that what they say may offend their black colleagues. In other words, the tone and substance of the conversation-the

30. On the point that when race is made more salient in a positive or justice-oriented context, people are less likely to engage in bias, see Gary Blasi, Default Discrimination: Law, Science, and Unintended Discrimination in the New Workplace, in BEHAVIORAL ANALYSES OF WORKPLACE DisCrimination: VOLUME IN HONOR OF DAVID B. ChaRNY (Michael J. Yelnosky \& Mitu Gulati eds., forthcoming 2005) (manuscript at 27, on file with Washington and Lee Law Review) (citing to research in the jury context); Nilanjana Dasgupta \& Anthony G. Greenwald, On the Malleability of Automatic Attitudes: Combating Automatic Prejudice with Images of Admired and Disliked Individuals, 81 J. PERSONALITY \& SOC. PSYCHOL. 800, 803-04 (2001) (finding that individuals exposed to pictures of Michael Jordan and Tiger Woods, prior to testing for bias, demonstrated reduced amounts of racial bias). There is also the related point that the presence of these role models might reduce the stereotype threat that scholars like Claude Steele have identified. See supra note 28 (citing material on stereotype threat).

31. See Rusty B. McIntyre et al., Alleviating Women's Mathematics Stereotype Threat Through Salience of Positive Group Achievements, 39 J. EXPERIMENTAL SOC. PSYCHOL. 83, 86 (2003) (finding that college women performed better on tests where they first read about four women who had been successes in their fields); see also Arlene G. Asuncion \& Diane M. Mackie, Undermining Social Stereotypes: Impact of Affect-Relevant and Behavior-Relevant Information, 18 BASIC \& APPLIED SOC. PSYCHOL. 367, 382-83 (1996) (finding that participants' willingness to apply stereotypes was undermined the most where inconsistent information presented was most directly relevant to the stereotypes). For further examination of these effects, see generally Rusty B. McIntyre et al., Social Impact of Successful Group Members on Improving Women's Performance Under Mathematics Stereotype Threat (2003) (unpublished draft) (on file with authors).

32. See Devon W. Carbado \& Mitu Gulati, What Exactly Is Racial Diversity?, 49 CaL. L. REV. 1149, 1159-62 (2003) (book review) (explaining that the mere presence of racial minorities can affect speech). 
discourse-will be shaped by the perception (which may or may not be real) that the black partners present are racially monitoring the conversation.

In addition to the foregoing discourse effect, black presence could also determine whether the partners accept the case. The white partners could believe that taking the case would so anger or alienate their black colleagues that it is against their long-term institutional interests to do so. One can imagine these monitoring effects occurring at other institutional moments as well; for example, during firm meetings about hiring and promotions. The presence of some minorities on the hiring and promotion committees might temper those who might otherwise be tempted to make arguments based on racial stereotypes-the discourse effect-and shape the bottom-line decisions the partners make about who to hire and promote-the outcome effect. ${ }^{33}$

Both discourse and outcome racial monitoring effects can be intensified via affirmative conduct or intervention by the person of color. ${ }^{34}$ If, in the above example, a black member of the firm's executive committee speaks to the racial implications of the firm taking an anti-affirmative action case, white partners will be even more careful about how they discuss the issue, and they will perhaps be less likely to take the case..$^{35}$ Active engagement, then, produces stronger monitoring effects than mere presence. ${ }^{36}$

33. See supra note 30 (presenting studies that show that when race becomes a salient issue, bias decreases).

34. The obligation to act affirmatively is discussed in a series of articles by David Wilkins about the "obligation thesis." David B. Wilkins, Essay: Identities and Roles: Race, Recognition, and Professional Responsibility, 57 MD. L. REV. 1502, 1556 (1998). For examples of Wilkins's research focusing on the related questions of (a) the obligations of those in the minority community who succeed in the corporate world to help their community and (b) whether the economic pressures that apply within institutions like corporate law firms allow for "doing well by doing good," see generally id.; David B. Wilkins, Two Paths to the Mountaintop? The Role of Legal Education in Shaping the Values of Black Corporate Lawyers, 45 STAN. L. REV. 1981 (1993).

35. Research suggests that the effect of making salient the danger that decisionmakers might be acting in a prejudiced manner can reduce the amount of prejudice (assuming that acting with prejudice is a disfavored behavior). See generally Steven J. Spencer et al., The Role of Motivation in the Unconscious: How Our Motives Control the Activation of Our Thoughts and Shape Our Actions, in Social Motivation: Conscious AND UnCONSCIOUS Processes (Joseph P. Forgas et al. eds., forthcoming 2004).

36. Active engagement will produce the strongest monitoring effect when it takes the form of institutional criticism. If, for example, a minority employee consistently engages the institution in conversations about the relationship between minority underrepresentation and the firm's selection and promotion processes, the partners may perceive that every hiring and promotion decision is being monitored. This perception could shape the outcome of the firm's hiring and promotion practices. 


\section{Racial Accountability}

Related to racial monitoring is racial accountability-the idea that white decisionmakers will have to account for any institutional decision that negatively affects nonwhites. Consider a firm that is contemplating extending offers to ten white attorneys. The accountability costs of the firm doing so is directly related to the number of people of color, particularly partners, at the firm. Put differently, the more people of color at the firm in leadership positions, the more difficult it will be for the firm to "account" for an entering class with no, or very few, people of color.

\section{Racial Cooperation}

Much corporate labor is performed in the context of teams. And the success of any given team is a function of whether and to what extent team members trust each other. The greater the level of trust among team members, the more efficient the team, and the more efficient the team, the more successful individual team members are likely to be. Race can be a barrier to the establishment of team trust. Nonwhites may be suspicious of the extent to which their white colleagues are invested in cooperating with them; whites may wonder whether nonwhites can be trusted to subordinate their racial identity commitments for the good of the team.

People of color in leadership positions can reduce racial distrust and facilitate racial cooperation. For one thing, senior minorities can provide input into the formation of teams to maximize opportunities for racial cooperation and minimize the likelihood of racial tensions and anxieties. For another, the very presence of senior people of color might suggest to whites that nonwhites can work effectively in teams and can be trusted, and nonwhites might conclude from senior minority presence that racial cooperation is possible. In short, the greater the presence of senior people of color, the greater the probability that nonwhites and whites will be more trusting of each other. They might even conclude that the differences among them are superficial, ${ }^{37}$

37. The statement in the text is an oversimplification. As research into the "contact" question has demonstrated, a number of conditions, such as equality of status, need to be satisfied before contact between the groups effectively can reduce prejudice. The research to this question derives from and builds on the classic work THE NATURE OF PREJUDICE by Gordon W. Allport, who set forth a set of conditions under which intergroup contact would reduce prejudice and enhance tolerance that have since been examined, modified, and re-examined. For a discussion of this hypothesis and the literature following Allport, see generally Marilynn B. Brewer \& Rupert J. Brown, Intergroup Relations, in 2 THE HANDBOOK OF SOCLAL 
and therefore that race ought not be a basis for judging a person's willingness and capacity to work in teams.

\section{E. Racial Comfort}

Part of the difficulty people of color experience working in predominantly white workplaces relates to racial comfort. ${ }^{38}$ Because nonwhite identity signifies racial difference and because this difference is perceived to cause grit not grease ${ }^{39}$ people of color have the burden of making whites feel comfortable with their nonwhite identity. ${ }^{40}$ The fewer people of color within the organization and the fewer minority success stories, the heavier the racial comfort burden. Conversely, the more people of color within a firm and the more minority success stories, the less intense white anxieties will be about racial difference and the capacity of nonwhites to fit comfortably within the predominantly white workplace. In this way, first generation minority successes help to diminish the amount of racial comfort work second generation employees have to perform. ${ }^{41}$ Put another way, first generation successes reduce the demand for, and the supply of, racial comfort work. ${ }^{42}$

Psychology 554 (Daniel T. Gilbert et al. eds., 1998); Miles Hewstone, Contact and Categorization: Social Psychological Interventions to Change Intergroup Relations, in STEREOTYPES AND STEREOTYPING 323 (C. Neil Macrae et al. eds., 1996); Michele Andrisin Wittig \& Sheila Grant-Thompson, The Utility of Allport's Conditions of Intergroup Contact for Predicting Perceptions of Improved Racial Attitudes and Beliefs, 54 J. Soc. IsSUES 795 (1998). For a discussion of this literature in the legal arena, see generally Cynthia L. Estlund, The Changing Workplace as a Locus of Integration in a Diverse Society, 2000 COLUM. BUS. L. REv. 331.

38. See generally Devon W. Carbado \& Mitu Gulati, Working Identity, 85 CORNELL L. REV. 1259 (2000) (discussing the concept of racial comfort).

39. See generally Langevoort, Grease and Grit, supra note 11.

40. See generally Carbado \& Gulati, supra note 19 (arguing that there is an incentive for institutions to maintain homogenous workplace cultures for the interrelated reasons of comfort and efficiency).

41. Racial comfort work is part of broader identity management strategy people of color employ to navigate predominantly white workplaces. For recent research on the topic of minority self-presentation and identity construction in majoritarian work settings, see generally Laura Morgan Roberts, Changing Faces: Professional Image Construction in Diverse Organizational Settings, ACAD. MGMT. REV. (publication forthcoming) (manuscript on file with the Washington and Lee Law Review); Sandra E. Cha \& Laura Morgan Roberts, Professional Image Construction Among Asian American Journalists: Strategies for Leveraging and Countering Stereotypes (Aug. 2004) (unpublished manuscript, on file with the Washington and Lee Law Review). For a fascinating treatment of the extra costs that minorities bear in terms of the consumer purchases (for example, purchasing high status goods like Remi Martin cognac, Brooks Brothers or Armani suits, and BMW cars) they make in order to counteract negative stereotypes, see generally Michèle Lamont \& Virág Molnár, How Blacks Use Consumption to 


\section{F. Role Modeling}

A standard argument for racial diversity is that it produces positive role modeling effects. ${ }^{43}$ Significantly, this argument is less about what people of color do at the top of the corporation and more about the fact that they are there. ${ }^{44}$ While the Supreme Court has rejected the argument that the benefits

Shape Their Collective Identity: Evidence from Marketing Specialists, 1 J. CONSUMER CULTURE 31 (2001).

42. For descriptions of the dynamics of this presentational dilemma and the risks that minorities face in negotiating their everyday identities in the workplace, see generally Carbado \& Gulati, supra note 38; Devon W. Carbado \& Mitu Gulati, Conversations at Work, 79 OR. L. REv. 103 (2000) [hereinafter Carbado \& Gulati, Conversations at Work]; Devon W. Carbado \& Mitu Gulati, The Fifth Black Woman, 11 J. CONTEMP. LEGAL IsSUES 701 (2001); Carbado \& Gulati, supra note 19.

43. See, e.g., Edward M. Chen, The Judiciary, Diversity, and Justice for All, 91 CAL. L. REV. 1109, 1116 (2003) (articulating the standard role modeling argument for racial diversity).

Diversity can establish the credibility of an institution, build bridges to other communities, and increase sensitivity to and awareness of diverse clientele and constituents. This is true whether the context is a union seeking to organize in a minority or immigrant community, a business looking to expand its markets to new communities, or a social service agency seeking to serve minority or culturally isolated populations.

[D]iversity provides role models for those historically excluded. It can provide a source of hope and inspiration for those who would otherwise limit their horizons and aspirations.

Id.; F. Michael Higginbotham, Affirmative Action in the United States and South Africa: Lessons from the Other Side, 13 TEMP. INT'L \& COMP. L.J. 187, 207 (1999) ("The existence of minorities in positions of prestige and power provides role models to young impressionable children. Having minorities employed in fields which have largely been dominated by white's [sic], opens children's eyes to many career possibilities."); Jonathan Alger, When Color-Blind Is Color-Bland: Ensuring Faculty Diversity in Higher Education, 10 STAN. L. \& PoL'Y REv. 191, 194 (1999) ("[O]ne argument [seeking to justify faculty diversity], often called the role model theory, holds that faculty of color in a variety of disciplines are seen as role models for underrepresented students of color.").

44. See, e.g., Sherrilyn A. Ifill, Racial Diversity on the Bench: Beyond Role Models and Public Confidence, 57 WASH. \& LeE L. Rev. 405, 481 (2000). (claiming that Justice Clarence Thomas was confirmed as a Supreme Court Justice because of his status as a role model). Ifill states:

[Clarence] Thomas was the first Supreme Court nominee who came to the nomination proceedings almost exclusively as a role model. Distinguishing himself in neither ... big law firm practice nor academia ... . Thomas's supporters advanced his race and his perseverance in overcoming childhood poverty and racism to the public as his principal qualifications for service on the Court. ... Thomas and his backers used Thomas's race and his experience with poverty to create an image of Thomas as the ultimate role model. 
of role modeling can function as a compelling state interest for affirmative action, ${ }^{45}$ the argument continues to have traction in academic and social contexts. ${ }^{46}$ Central to the role modeling argument is the notion that at least

Id. Ifill goes on to say:

While Thomas's backers viewed him as a black role model, to many blacks, Thomas was not a role model. In fact, given his record . . . , his political views, . . . and his disparaging remarks about well-regarded black leaders, most blacks would have considered Thomas the very opposite of a role model. . . .

$\cdots$

Despite [many black leaders' and civil rights organizations'] disagreement with nearly all of Thomas's positions on civil rights issues, a majority of blacks supported Thomas .... Some advocated supporting Thomas because they feared that if Thomas were not confirmed, President Bush would appoint a white candidate to fill the position.

Id. at 482-83; Adeno Addis, Role Models and the Politics of Recognition, 144 U. PA. L. REv. $1377,1384 \mathrm{n} .20$ (1996) (referring to Cornel West's analysis of Justice Thomas's confirmation). Addis states:

Discussing what he saw as the racial reasoning of the black leadership that prevailed during the Clarence Thomas/Anita Hill Senate hearing, [Cornel West] comments: "Unfortunately, most black leaders remained caught in a framework of racial reasoning - even when they opposed Thomas and/or supported Hill. Rarely did we have a black leader highlight the moral content of a mature black identity, accent the crucial role of coalition strategy in the struggle for justice, or promote the ideal of black cultural democracy. Instead, the debate evolved around glib formulations of a black 'role model' based on mere pigmentation ...."

Id. (quoting CORNel West, Race MATtERS 31 (1993)); Maya Angelou, I Dare to Hope, in Court of Appeal: The Black Community SpEaKs Out On the Racial and SEXual Polrtics of ClaRence Thomas vs. ANITA Hill 33, 35 (Robert Chrisman \& Robert L. Allen eds., 1992) ("Because Clarence Thomas has been poor, has been nearly suffocated by the acrid odor of racial discrimination, is intelligent, well trained, black and young enough to be won over again, I support him.").

For a more general discussion of the race and gender politics implicated in Clarence Thomas's judicial appointment, see Devon W. Carbado, The Construction of O.J. Simpson as a Racial Victim, 32 HARV. C.R.-C.L. L. REV. 49, 77-81 (1997).

45. See Wygant v. Jackson Bd. of Educ., 476 U.S. 267, 275-76 (1986) (refusing to utilize the role model theory); Regents of the Univ. of Cal. v. Bakke, 438 U.S. 265, 305-10 (1978) (refusing to consider remedying the amorphous effects of past "societal discrimination" a compelling state interest).

46. See, e.g., John Valery White, What Is Affirmative Action?, 78 TUL. L. REV. 2117, 2168 n.241 (2004) (commenting that the contours of the academic debate over affirmative action are well known). White states:

Supporters [of affirmative action] retort that the relationship between African Americans and whites is hardly symmetrical, and that racial preferences are necessary to remedy discrimination, to provide role models for the disadvantaged, and to increase diversity.... Although little new can be said about these arguments, the dispute continues with no sign of resolution.

Id.; Eric A. Tilles, Lessons from Bakke: The Effect of Grutter on Affirmative Action in 
one barrier to people of color moving up the corporate hierarchy is the difficulty they have imagining themselves there. ${ }^{47}$ The greater the extent of racial underrepresentation at the upper echelons of the corporation, the more difficult this racial imagining. Conversely, the more diverse the corporate boardroom and the more successful the people of color there, the greater the likelihood that junior people of color will imagine themselves occupying similar positions of power and authority. In sum, the basic role modeling insight is that the presence of people of color at the top of the corporation sends a positive message to people of color at the bottom that they, too, can ascend the corporate hierarchy.

\section{G. Tokenism}

Subsequent to the passage of antidiscrimination laws, workplace scholars identified tokenism as a significant barrier to minority success. ${ }^{48}$ Tokenism

Employment, 6 U. PA. J. LAB. \& EMP. L. 451, 460 (2004) (explaining some scholars' arguments that the Grutter v. Bollinger, 539 U.S. 306 (2003), opinion seems to approve of the role model theory that Wygant rejected and countering that "the closest Grutter comes to arguing in favor of the role model theory is ... [that it advances] the legitimacy of societal leadership, not models for minority students to follow").

47. See Richard Delgado, Essay: Affirmative Action as a Majoritarian Device: Or, Do You Really Want to Be a Role Model?, 89 MICH. L. REV. 1222, 1223 n.5 (1991) (explaining the role model argument.).

The role model argument, in simplest form, holds that affirmative action is justified in order to provide communities of color with exemplars of success, without which they might conclude that certain social roles and professional opportunities are closed to them. Role models are expected to communicate to their communities that opportunities are indeed available and that hard work and perseverance will be rewarded.

Id. (citations omitted).

48. The classic work on tokenism and the burdens that come associated with it is ROSABETH MOSS KANTER, MEN AND WOMEN OF THE CORPORATION (2d ed. 1993). Kanter's focus was on women and the dynamics with respect to other groups such as racial minorities are likely to be different. For more recent discussions, see Louise Marie Roth, The Social Psychology of Tokenism: Status and Homophily Processes on Wall Street, 47 SOC. PERSP. 189, 208-10 (2004) (finding that tokenism effects are diminished in the presence of objective evaluations, mentors, and specialized skills); Michael J. Yelnosky, The Prevention Justification for Affirmative Action, 64 OHIO ST. L.J. 1385, 1389-99 (2003) (reviewing and discussing the recent literature on tokenism). Cf. Christine L. Williams, The Glass Escalator: Hidden Advantages for Men in the "Female" Professions, 39 Soc. ProBs. 253, 263 (1992) (finding that the disadvantages that men face in female-dominated professions are significantly different from those that women face in male-dominated fields). See generally Elizabeth Chambliss \& Christopher Uggen, Men and Women of Elite Law Firms: Reevaluating Kanter's Legacy, 25 LAW \& SOC. INQUIRY 41 (2000). 
refers to instances in which a firm (a) hires a small number of persons of color and (b) does little to integrate them into the firm culture. A firm's reason for practicing tokenism will not always be invidious. But whatever intentionality underwrites the practice, one of its institutional effects is simultaneously to legitimize the existence of a predominantly white workplace and provide the firm with a defense against discrimination. The rhetorical form this legitimation defense takes looks something like this: "It is true that most of our associates are white. However, it is not true that we discriminate against Asians. We hired Mathew, a Korean American, last year, and we are hopeful that we will hire more people like Mathew in the future."

Tokenism burdens people of color in three significant ways. First, tokenism burdens the token with the weight of representing his entire race. The cost of his failure is imposed not simply on him but on his race as a whole. Consequently, the token's every action is racially representative. ${ }^{49}$ He becomes his race and, more particularly, an indication of the potential - or lack thereofof his race. Second, tokenism limits the token's sense of autonomy. His interactions will likely be overdetermined by his awareness of the representative function his identity performs. For example, Mathew, the Korean-American executive, might avoid interacting with technical support staff out of fears that it might racially represent his group as technically but not creatively inclined. A third problem with tokenism is that it requires the token to negotiate his belonging. The very reason he is a token likely derives from the perception (which may or may not be conscious) that members of his race do not belong. The token has to be careful not to internalize this idea, and he has to be vigilant about counteracting it.

The success of the first generation (most of whom were tokens) and their presence at the top of corporate hierarchies reduces the racial representation burdens of later generation employees. The conduct of these employees will be less racially representative, giving them greater autonomy to navigate the workplace and a greater sense of entitlement and belonging.

\section{H. Mentorship}

Success within most large bureaucratic organizations requires access to tacit information about both the organization (for example, how to negotiate institutional politics) and the job (for example, how to communicate with clients). ${ }^{50}$ The defining characteristic of this tacit information is that it has to

49. See Yelnosky, supra note 48, at 1390-99 (describing the dynamics of tokenism).

50. In the law firm context, this information is described in David B. Wilkins \& G. Mitu 
be conveyed in person. What this means, more specifically, is that senior employees have to take junior employees under their wing. The ideal situation is one in which senior employees "group mentor" junior employees, which is to say they constitute themselves as a group - a network of information-for the juniors. ${ }^{51}$ This network would then provide juniors with invaluable official and unofficial knowledge about the institution, its governance structure, and power brokers.

The reasons that people of color typically do not have access to this kind of institutional knowledge are complicated; the answer is not simply intentional racial animus. ${ }^{52}$ Part of the problem may be that scarce mentorship resources are allocated to those with whom the mentors are most comfortable, and these may tend to be juniors of the same race and gender as the mentors. ${ }^{53}$

Gulati, Why Are There So Few Black Lawyers in Corporate Law Firms? An Institutional Analysis, 84 CAL. L. REV. 496 (1996). See generally Pamela J. Smith, Failing to Mentor Sapphire: The Actionability of Blocking Black Women from Initiating Mentoring Relationships, 10 UCLA WOMEN's L.J. 373, 389-90 (2000); MARGO MURRAY \& MARNA A. OWEN, BEYOND THE MYTHS AND MAGIC OF MENTORING (1991); Scott E. Seibert et al., A Social Capital Theory of Career Success, 44 ACAD. MGMT. J. 219 (2001).

51. Put differently, the concept is that individuals rely on not just a single mentor for developmental support, but on a "relationship constellation." Monica C. Higgins \& Kathy E. Kram, Reconceptualizing Mentoring at Work: A Developmental Network Perspective, 26 ACAD. MGMT. REV. 264, 264 (2001).

52. David Wilkins describes the importance of having access to networks that can provide such information in the context of the story of Lawrence Mungin, a black lawyer who makes a number of strategic errors in his attempt to move up the corporate hierarchy. See David B. Wilkins, On Being Good and Black, 112 HARV. L. REV. 1924, 1966 (1999) (book review) (describing how Mungin cut himself off from possible sources of information about the law firm's informal processes in the black community). The importance of having access to social networks forms the basis for much of Glenn Loury's writing about the economics of discrimination. See, e.g., Glenn C. Loury, Discrimination in the Post-Civil Rights Era: Beyond Market Interactions, J. ECON. PERSP., Spring 1998, at 119-21 (arguing that social networks, which largely determine one's access to resources; allow past discrimination to persist over time and can have deleterious impacts on skills among minorities and significantly contribute to racial inequalities).

53. See David A. Thomas \& John J. Gabarro, Breaking Through: The Making of MINORITY EXECUTIVES IN CORPORATE AMERICA 26 (1999) (observing, in the context of a study of the difficulties that black executives face in advancing up the corporate hierarchy, that white men often find it more comfortable working with other white men). See generally Raymond A. Friedman \& Brooks Holtom, The Effects of Network Groups on Minority Employee Turnover Intentions, 41 HUM. RESOURCES MGMT. 405 (2002) (describing the background literature on the barriers to mentorship for minority employers and finding that the presence of "network groups" can help alleviate that problem); David A. Thomas, Racial Dynamics in Cross-Race Developmental Relationships, 38 ADMIN. SCI. Q. 169 (1993) (describing the barriers that racial differences can erect to the creation of effective mentorship relationships). On the importance of mentorship relationships for lawyers in general and minority lawyers in particular, see generally Monica C. Higgins \& David A. Thomas, Constellations and Careers: Toward 
An alternative explanation is that tacit information is often conveyed in informal settings-settings in which people are relatively comfortable engaging in office gossip about the ins and outs of workplace politics. People of color may have limited access to these settings, again because after-work socialization tends to be same-race. ${ }^{54}$

The first generation of minority successes occurred despite minimal access to the foregoing information networks. In some cases the success was a result of exceptional skill, in other cases it was luck, and in still other (presumably rare) cases there was some nonminority who was willing to reach outside an established ingroup to provide mentorship and network opportunities to a minority protégé. ${ }^{55}$ The workplace presence and success of the first generation means that succeeding generations of minorities will have access to at least a minimal amount of mentorship and networks, reducing the need to rely on exceptional skill, luck, benevolence, and outside connections.

Understanding the Effects of Multiple Developmental Relationships, 22 J. ORG. BEHAV. 223 (2001) (finding that a lawyer's portfolio of mentoring relationships is crucial in determining the occupational path he or she takes); David Thomas \& Monica Higgins, Mentoring and the Boundaryless Career: Lessons from the Minority Experience, in THE BOUNDAR YLESS CAREER: A New EMPloyment Principle for a New ORganizational ERa 268 (Michael B. Arthur \& Denise M. Rousseau eds., 1996) (describing how minority employees, who can be at a disadvantage in terms of accessing intrafirm networks of information, are sometimes able to reach outside their own firms' race-based networks of information).

54. See Wilkins \& Gulati, supra note 50, at 569-70 (arguing that black associates at large firms often have a difficult time of establishing mentoring relationships necessary to be privy to tacit information partly because white mentors prefer associates who remind them of themselves); see also Nijole V. Benokraitis \& Joe R. Feagin, Sex Discrimination: Subtle and Covert, in Down To EARTH Sociology 334, 334-35 (James M. Henslin ed., 7th ed. 1993) (describing the informational inadequacy problem that arises as a result of being excluded from informal social groups at the workplace).

55. See, e.g., Jonathan Kaufman, Inside Outsiders: As Blacks Rise High in the Executive Suite, CEO is Often Jewish, WALL ST. J., Apr. 22, 1998, at A1 (describing a mentoring relationship between two Jewish partners at a major New York law firm and a young black associate who later became a partner). As Thomas describes, there are significant barriers to such cross group mentorship. Thomas, supra note 53. What Wilkins interestingly finds in the law firm context is that the first generation of minority successes often came in laterally, after what was usually a distinguished career in public service. David B. Wilkins, Partners Without Power?: A Preliminary Look at Black Partners in Corporate Law Firms, 2 J. INST. FOR STUDY LEGAL ETHICS 15, 30-31 (1999). Wilkins argues in a more recent paper that minority associates and partners, because of their reduced access to intrafirm networks, often have to tap into networks outside their firm-networks that often involve public service to the larger minority community. David B. Wilkins, Doing Well by Doing Good? The Role of Public Service in the Careers of Black Corporate Lawyers, 41 Hous. L. REV. 1, 29-30 (2004). In other words, they did not succeed in the usual manner. The fact that they came in laterally at a later stage, however, usually meant that they did not have a large store of institution-specific tacit knowledge to help their successors. Indeed, despite their partner status, they were usually struggling for survival themselves. Id. at 35-47. 
Having set forth the results that many of us hope will accrue from the successes of the first generations of minorities in the workplace-in other words, the dynamics of the "trickle down" effect-the next question is: What are the characteristics of the minorities most likely to succeed? This is the subject of Part III. Engaging this question allows us to explore whether successful racial minorities are likely to perform the ameliorative functions relating to stereotype negation, racial monitoring, racial accountability, racial comfort work, tokenism, and mentorship.

\section{Those Most Likely To Succeed}

Starting with the assumption that racial minorities are subject to negative stereotypes-negative presumptions about work ethic, loyalty, trustworthiness, and collegiality, among other things-we walk through a set of three simple predictions about the types of minorities likely to succeed in predominantly white corporate cultures. ${ }^{56}$ As will become clear, we model success as a function of choices. We do so not to deny the institutional constraints of being a person of color in a modern corporate culture. Indeed, it is precisely because we recognize these constraints that we focus on choice-how minorities exercise the limited discretion they have with respect to work assignmentsand on what we call racial agency-how senior and presumably successful minorities manage the presence of other junior minorities within the corporation. We argue that there is a relationship between being a successful racial type and the exercise of racial agency. More particularly, our claim is

56. This subject has been the focus of our joint research over the past few years. See generally Carbado \& Gulati, supra note 38 (examining the use of workplace identities by minorities to negate the effects of stereotyping). For other research on how individuals negotiate their identities as a function of discriminatory perceptions in the workplace, see generally W.E. Douglas Creed \& Maureen A. Scully, Songs of Ourselves: Employees' Deployment of Social Identity in Workplace Encounters, 9 J. MGMT. INQUIRY 391 (2000); Robin J. Ely, The Role of Dominant Identity and Experience in Organizational Work on Diversity, in DIVERSITY IN WORK TEAMS: RESEARCH PARADIGMS FOR A CHANGING WORKPLACE 161 (Susan E. Jackson \& Marian N. Ruderman eds., 1995); Roberts, supra note 41. More broadly, on the concerns that drive an employee's choices regarding an image construction in the workplace, see generally PAUL ROSENFELd ET AL., IMPRESSION MANAGEMENT IN ORGANIZATIONS (1995); Susan J. Ashford et al., Out on a Limb: The Role of Context and Impression Management in Selling Gender-Equity Issues, 43 ADMIN. SCI. Q. 23 (1998); Caroline Bartel \& Jane Dutton, Ambiguous Organizational Memberships: Constructing Organizational Identities in Interactions with Others, in SOCIAL IDENTITY PROCESSES IN ORGANIZATIONAL CONTEXTS 115 (Michael A. Hogg \& Deborah J. Terry eds., 2001); Erica Gabrielle Foldy, Being All That You Can Be: Identities and Interactions in Organizations (Harvard Bus. Sch., Working Paper No. 03-117, 2004) (unpublished manuscript, on file with Washington and Lee Law Review). 
that the racial types who race their way to the top of the corporate hierarchy, "successful racial types," are not likely to exercise racial agency to "lift [others] as they climb." explicitly articulate the nature or identity characteristics of successful racial types. We do so below.

\section{A. Risk-Taking, Luck, and Overconfidence}

The simplest models of employee promotion are production-centered. According to these models, the employee who produces the most widgets at the cheapest cost will be promoted. The theory is that the employer is competing with other employers to produce the cheapest and best widgets; therefore, the employer who does not promote the best widget-producers will lose them to the job market and ultimately be driven out of business.

The reality in most large organizations is quite different. Employee performance is often difficult to measure; moreover, many corporate tasks are structured so that employees are required to exercise discretion. If, as we are suggesting, minority employees are often subject to stereotypes that they are less capable, the question emerges as to how they will exercise this discretion. We contend that there is an incentive for minorities to exercise discretion to counteract or to undermine the negative stereotype about competence. One way for them to do so is to assume primary responsibility for high-risk tasks, tasks that are well beyond their skill level and that have the potential to make them stand out among their peers. High-risk projects, when performed successfully, yield high returns. Taking on and successfully completing a difficult project that people at low levels of experience do not usually attempt might catch the attention of the corporate leaders and cause them to rethink their racial assumptions. It makes sense, then, for people of color seeking advancement to make this highrisk choice.

This will not necessarily be the case for whites. Because whites are not subject to negative stereotypes, they will experience less pressure to take on highrisk assignments. If we assume that whites and nonwhites are in a competitive race to the top of the corporation, one way for minorities to gain a competitive edge, or at least mitigate a racial disadvantage, is to perform high-risk tasks. And, indeed, there is some suggestion in the employment discrimination literature that the people of color who are most likely to succeed in the corporate context (apart from the true superstars) are those who (a) take big risks and

57. See supra note 2 and accompanying text (showing the extent to which this concept has permeated the general consciousness). 
(b) are lucky in that the big risks pay off. ${ }^{58}$ While we agree that risk-taking and luck help to explain minority corporate success, we believe that a third factor or condition plays a role as well: overconfidence. If the firm attributes an employee's success to luck, the firm probably will not promote that employee. Nor is the firm likely to look favorably upon excessive risk-taking behavior, particularly if the firm bears the costs of the failures. Consequently, the employee who is seeking to outperform his colleagues cannot stop at taking higher risk gambles. He must also be able to persuade the firm's decisionmakers that the successes that result from these gambles were earned and not the result of luck. Likely, excessively self-confident minorities will be persuasive on this score. The firm will perceive these employees to be "authentic" in their claim that their success was a function of talent, not luck. ${ }^{59}$ In sum, risk-taking, luck,

58. See, e.g., Carbado \& Gulati, supra note 38, at 1289-90 (describing how the dynamic can occur in everyday workplace image management choices); David Charny \& G. Mitu Gulati, Efficiency-Wages, Tournaments, and Discrimination: A Theory of Employment Discrimination Law for "High-Level" Jobs, 33 HARV. C.R.-C.L. L. REV. 57, 79 (1998) (explaining the structural dynamic that produces an incentive for minority workers to take on high-risk gambles); Wilkins \& Gulati, supra note 50, at 522-23 (explaining this dynamic in the context of law firm promotions). Although not often explicitly described as a high-risk gamble, scholars in the gender discrimination area have also identified the same dynamic as occurring when women employees have to attempt to negate the stereotypes of being meek but then risk overcompensating and activating the other negative stereotype of being unfeminine or pushy. See, e.g., ViRgINIA VALIAN, WhY So SLOW? THE ADVANCEMENT OF WOMEN 133-37 (1998) (reexamining the tradeoffs of appearing masculine or feminine); $c f$. Carol T. Miller \& Anna M. Meyers, Compensating for Prejudice: How Heavyweight People (and Others) Control Outcomes Despite Prejudice, in PREJUdiCE: THE TARGET's PERSPECTIVE 191, 212 (Janet K. Swim \& Charles Stangor eds., 1998) (describing how the attempt to compensate for negative stereotypes can sometimes result in overcompensation where someone talks too fast, laughs too loud, or comes on too strong, and ends up putting off other people instead of pleasing them). Finally, for those outsider employees who try to demonstrate affinity for the dominant group, there is also the danger of being perceived as a traitor by their own group. See Nyla R. Branscombe \& Naomi Ellemers, Coping with Group-Based Discrimination: Individualistic Versus Group-Level Strategies, in PREJUDICE: THE TARGET's PERSPECTIVE 243, 258 (Janet K. Swim \& Charles Stangor eds., 1998) (discussing the long term risks and benefits that individuals who remove themselves from their group face).

The dynamic described in the text is particularly likely to occur in up-or-out settings where both the rewards for success and the penalties for failure are large. If, however, the penalty for failure in that partner game is not large, then the high-risk dynamic described in the text can be reversed in a way that those with an a priori lower likelihood of success are pushed towards excessive risk aversion. In law firms, even though there is supposedly an "up-or-out" system, the "out" part is not generally a high penalty because those who fail in obtaining partnership can generally get "high" or "efficiency" wage jobs elsewhere.

59. On the importance of authenticity for effective impression management, see Roberts, supra note 41 (manuscript at 33-36) (citing to studies to support the point that those who demonstrate authenticity are likely to be more effective in their impression management strategies). 
and overconfidence are three important and interrelated factors in the determining whether minorities will ascend the corporate hierarchy.

\section{B. Team Work and Racial Fit}

As previously discussed, a large percentage of corporate work is performed in the context of teams. ${ }^{60}$ Thus, one's ability to climb the corporate ladder is a function of one's competence as a team worker and one's reputation as a team player. There is a growing body of literature suggesting that corporate leaders likely presume that people of color will not fit comfortably within team-oriented environments. ${ }^{61}$ The presumption, more specifically, is that people of color are different, that their loyalties reside outside of the institution, and that they have suspicions about, feel uncomfortable around, and are also distrusting of their white counterparts. To the extent that people of color are aware of this negative presumption regarding their capacity for institutional fit, there is an incentive for them to demonstrate not simply that they can, in fact, teamwork, ${ }^{62}$ but that they can do so more effectively than

60. See supra Part II.D (discussing the role of trust in teamwork).

61. The development of open, trusting, and genuine relationships is crucial for the setting up of effective teams. See Amy Edmonson, Psychological Safety and Learning Behavior in Work Teams, 44 ADMIN. SCI. Q. 350, 354-55 (1999) (stating the importance of trust on the team level rather than just among team members). There are two bodies of research that bear on this point that racial minorities are likely to have difficulty in matching up to their white male counterparts on these criteria. First, research shows that perceived similarity and ingroup-ness positively influences the likelihood of trust and liking, crucial precursors for setting up effective teams. See generally Roderic M. Kramer et al., Collective Trust and Collective Action: The Decision to Trust as a Social Decision, in TRUST IN ORGANIZATIONS: FRONTIERS OFTHEORY AND RESEARCH 357 (Roderic M. Kramer \& Tom R. Tyler eds., 1996); Charlan Jeanne Nemeth, Differential Contributions of Majority and Minority Influence, 93 PSYCHOL. REV. 23 (1986); Jeffrey T. Polzer et al., Capitalizing on Diversity: Interpersonal Congruence in Small Work Groups, 47 ADMIN. SCI. Q. 296 (2002). And then there is a large body of research on the types of negative stereotypes racial minorities face that, depending on the minority identity in question, can include laziness, untrustworthiness, lack of intelligence, lack of creativity, and foreignness. See generally Patricia G. Devine, Stereotypes and Prejudice: Their Automatic and Controlled Components, 56 J. PERsonaliTY \& SOC. PsYCHOL. 5 (1989); Sandy JeanquartBarone, Implications of Racial Diversity in the Superior-Subordinate Relationship, $26 \mathrm{~J}$. APPLIED SOC. PSYCHOL. 935 (1996); Lisa Sinclair \& Ziva Kunda, Reactions to a Black Professional: Motivated Inhibition and Activation of Conflicting Stereotypes, $77 \mathrm{~J}$. PERSONALTTY \& Soc. PSYCHOL. Bull. 885 (1999); Cha \& Roberts, supra note 41.

62. See Francis J. Flynn et al., Getting to Know You: The Influence of Personality on Impressions and Performance of Demographically Different People in Organizations, 46 ADMIN. SCI. Q. 414, 419 (2001) (finding that demographically different persons who are better able to self monitor are more likely to be able to succeed in workplace settings). 
their white (typically male) counterparts. $^{63}$ To put the point more controversially, there is an incentive for minorities to prove that they can be better insiders than white men. And those who exhibit the greatest insidergroup affinity are most likely to receive promotions.

\section{Managing Other Minorities}

The reality of the modern workplace is that racial minorities are going to be present. The "racial problem" for firms is no longer how to keep people of color out but rather (a) making a determination as to which ones to let in and (b) developing strategies for managing them. In other words, firms are going to want to hire and promote some minorities. As suggested earlier with respect to hiring, because of concerns about racial comfort and institutional fit, ${ }^{64}$ firms will screen for racial palatability and against performative racial difference. Concretely and employing blacks as an example, firms will hire people who

63. Along these lines, a number of commentators recommend that outsiders-those with different social identities-de-emphasize those social identity differences and instead emphasize work-related commonalities so as to achieve cohesion and unity at the workplace. See generally Scott Allison \& Caryn E. Herlocker, Constructing Impressions in Demographically Diverse Organizational Settings, 37 AM. BEHAV. SCIENTIST 637 (1994); Jennifer A. Chatman et al., Being Different Yet Feeling Similar: The Influence of Demographic Composition and Organizational Culture on Work Processes and Outcomes, 43 ADMIN. SCI. Q. 749 (1998); John F. Dovidio et al., Reducing Contemporary Prejudice: Combating Explicit and Implicit Bias at the Individual and Intergroup Level, in REDUCING PREJUDICE AND DisCRIMINATION (Stuart Oskamp ed., 2000).

There is a body of research that finds that the above prescriptions do not always need to hold for diverse teams to function effectively. If the organizations themselves set up structures that value social identity differences, then employees will feel less of a need to adopt the kinds of strategies mentioned above. Instead, their differences can, in some cases, be harnessed to achieve productivity gains. See Robin J. Ely \& David A. Thomas, Cultural Diversity at Work: The Effects of Diversity Perspectives on Work Group Processes and Outcomes, 46 ADMIN. SCI. Q. 229, 240-43 (2001) [hereinafter Ely \& Thomas, Cultural Diversity at Work] (examining the potential value of diverse individual cultural experiences to the group process); Robin J. Ely \& David A. Thomas, Team Learning and the Racial Diversity-Performance Link 26-31 (Aug. 2004) (unpublished manuscript, on file with Washington and Lee Law Review) (analyzing the impact of racial learning environments on performance measures); see also Manuela Barreto \& Naomi Ellemers, The Impact of Respect Versus Neglect of Self-Identities on Identification and Group Loyalty, _ PERSONALITY \& SOC. PsYCHOL. BuLL. (forthcoming 2005) (manuscript at 14 15, on file with Washington and Lee Law Review) (finding that a person's identity presentational choices, including which aspects of their identity to emphasize and which aspects to de-emphasize, are a function of how the organizational culture treats those different identities).

64. See supra Part II.E (arguing that racial minorities bear the burden of making whites comfortable with the minority presence). 
are phenotypically but unconventionally black-that is to say, people who "look" but do not "act" black.

With respect to promotion, firms likely will have an additional concern, a concern that derives from what we call residual racial difference. Notwithstanding the firm's best screening efforts, the minorities that the firm hires will still be different. They cannot perform their way completely outside their racial identity; they will always be intelligible as nonwhite-less nonwhite than other people of color, to be sure, but nevertheless nonwhite. Firms will want to promote people of color who can help the firm manage this residual racial difference or racial excess. A crucial element of that management task will be to devise a mechanism both to provide and to receive information across the groups. Minorities in key management positions can be effective conduits for this information. There is an incentive, then, for firms to promote those minorities with the capacity to help them better manage and communicate with the larger group of minority workers in the workplace.

This management concern may also extend to minority groups outside the firm. If a firm needs to cultivate customers or clients in minority communities, and there is a perception that minority employees are better able to serve as conduits, there is an incentive for the firm to promote at least some minority employees who can assist in managing these external relationships.

\section{Summary}

Our point of departure for this Part was to model employee success as a function of employee choice. We did so to identify the kind of choices minority employees will have to make to ascend the corporate hierarchy and to reveal how the exercise of those choices produces a particular type of racial subjectivity-a person of color who (a) is both a risk-taker and overly confident, (b) is a team player, and (c) is perceived by the employer to have the capacity to manage other nonwhites. The question is now whether this type of racial minority is likely to perform the discrimination-ameliorative tasks outlined in Part II. We now turn directly to this question.

\section{The Likelihood of Ameliorative Tasks Being Performed}

Assuming that the minority employee actually races her way to the top of the corporation, the ameliorative tasks set forth in Part II seem easy to perform. Indeed, many of these tasks get "performed" simply as a function of the minority employee's presence at the upper echelons of the workplace. But once one takes 
into account the significant behavioral incentives that confront minority employees, incentives that derive from the perception of negative stereotyping, the racial "difficulty" of performing discrimination-ameliorative tasks becomes more apparent. Below we indicate the precise nature of this difficulty with respect to each of the ameliorative tasks we discussed in Part II.

\section{A. Stereotype Negation}

We begin our analysis of the trickle down benefits via a discussion of stereotype negation. We suggested that there are two stereotype-negating strategies that senior minorities can employ-racial group negation strategies and individual identity negation strategies - and that the employment of either or both of these strategies would racially improve the corporation for junior minorities. However, as we explain below, there is a greater incentive for seniors to perform individual identity negation strategies than group negation strategies, and the former do little to improve the advancement opportunities of junior minorities.

\section{Racial Group Negation Strategies}

\section{a. The Difficulties of Direct Intervention}

Imagine that Marco, a Latino, is interested in convincing the decisionmakers at his firm that Latinos are not lazy and that they are just as competent as whites. He could, in the context of a hiring meeting, simply remind his colleagues of the way stereotypes work and suggest that they be careful not to allow their decisionmaking to be informed by those stereotypes. This need not be done in a confrontational manner. Indeed, Marco might even employ humor to raise the racial consciousness. ${ }^{65}$

This kind of direct intervention-speaking out about racial stereotypes in the context of a hiring meeting -is not likely to occur, however. To understand why, one has to conceptualize the hiring meeting as a high visibility moment, a moment in which one's institutional identity is salient. Recall now the composite of the people of color who are most likely to ascend the corporate hierarchy; these people will probably be overconfident about their abilities, be willing to take high levels of risk, and be able to credibly demonstrate an affinity for the dominant group. Given the nature of the

65. See Cha \& Roberts, supra note 41 , at 6-9 (observing the different strategies used to negate stereotypes, including the humor strategy). 
modern corporation (complex hierarchies with decentralization), high visibility moments are few and far between. ${ }^{66}$ They are occasions, therefore, in which an incentive exists for employees, especially nonwhite employees, to engage in identity management strategies to positively construct their individual institutional identity. This incentive renders the hiring meeting a suboptimal occasion for Marco to confront authority-even via humor. ${ }^{67}$ Likely Marco will want to use the hiring meeting to solidify the impression of him as an affable, and not a hostile, person of color who is loyal to the firm and committed to its institutional projects.

One might reasonably raise the question as to why Marco's risk-taking tendencies would not result in him being interventionist. Being silent in the context of a hiring meeting in which the operation of stereotypes could limit opportunities for people of color hardly seems like something a risk-taker would do. But note that Marco's risk-taking is in respect to job assignments, not overall institutional politics. He engages in risk-taking only to the extent that he perceives a stereotype negation payoff. And none seems to flow from admonishing one's colleagues to be careful not to draw on stereotypes when making hiring decisions.

One may conclude from the foregoing discussion that Marco has two choices: (1) not speaking out about stereotypes, a passive move that leaves his racially affable institutional identity in tact, or (2) speaking out against the operation of racial stereotypes, an active move with the potential to disrupt his "positive" racial image. However, Marco has a third option: to very subtly sanction his colleagues' utilization of stereotypes. In the context of the meeting, he might simply say something like:

Some of you have expressed concerns about the small number of people of color-especially Latinos-in the pool. One of you made the point that we cannot have another year in which we fail to hire at least one Latino. As a Latino myself and a member of this firm for over twelve years, I would certainly like to see others at this firm. But I don't think we should lower our standards, and I don't think we should be paternalistic. Let's not forget that, up until two years ago, there were three other Latinos in this firm. Two left to pursue other opportunities and one was denied partnership for good reason. He simply was not a team-player, and he did not have the best work ethic. That's not a bad racial record. Could it be better? Perhaps. I would need to do some more thinking about it. To be clear: none of this is to say that we should be unmindful of the possibility

66. See Carbado \& Gulati, Conversations at Work, supra note 42, at 103-07 (discussing the concept of high visibility).

67. $C f$. Derrick A. Bell, Confronting Authority: Reflections of an Ardent PROTESTOR 9-25 (1994) (providing "models for confrontation"). 
that our hiring produces a racially disparate impact. What I am suggesting here is that there is no indication that this is the case. From where I sit, then, I think we should stop beating ourselves up about this. I say all of this as a Latino who is deeply concerned about the well being of Latinos inside and outside of this firm.

Marco's speaking out in this way solidifies the impression of him as a team-player who is loyal to the institution, invested in merit, and willing to subordinate racial group identity politics for the good of the firm. His colleagues could read his comments to say, vis-à-vis hiring, the firm is doing nothing wrong; to the extent there are few Latinos at the firm, that is a function of the limited number of qualified Latinos, not racial discrimination. If so, Marco will have demonstrated to his white colleagues in power (a) a lack of resentment about the possibility of their holding negative racial stereotypes, and (b) an affirmative belief in the meritocratic nature of the workplace. ${ }^{68}$ In all of this Marco remains authentic as a Latino. At no time does he disidentify with the identity category "Latino" or with the idea of race or racial organization.

Marco's intervention could signal an even stronger commitment to the firm and a weaker commitment to racial group identification. Marco could make the point that, given affirmative action, it is particularly important to pay attention to standards when hiring minorities. This might translate into Marco applying a higher level of scrutiny to minority applicants; he may even insist that marginal minority candidates not be hired, even where marginal candidates from other groups are hired. If Marco adopts this strategy, it will likely allay any concerns about his institutional commitment. But it will also provide those colleagues with an external justification for their negative actions regarding minority issues. For example, it is a lot easier for a law firm to explain its defense of some egregiously discriminatory position being advanced by a client if it is able to assert that its minority lawyers insisted, on the grounds of principle, that they not deny that client representation. Along similar lines, it would help the firm defend a discrimination case filed by a

68. See Elijah Anderson, The Social Situation of the Black Executive: Black and White Identities in the Corporate World, in THE CULTURAL TERRITORIES OF RACE: BLACK AND WHITE BOUNDARIES 3, 9 (Michèle Lamont ed., 1999) (describing how many successful blacks internalize conceptions of the organization as a meritocracy and are willing to blame whatever bad experiences they have had on aberrant individuals); $c f$. David A. Thomas, Diversity as Strategy, HARV. BuS. REV., Sept. 2004, at 98, 102 (noting, in a description of IBM's recent strategic initiative to improve diversity at the firm, how members of the black task force advocated for a conservative approach to diversity because of the fear that they would be perceived as asking for "unearned preferences, and, even worse, might encourage the stereotype that blacks are less capable"). 
former employee of color if the people who led the charge for the denial of promotion were themselves members of a minority group.

Whether, in the above hypothetical, Marco would go so far as to lead the charge against hiring another Latino is not clear. What is clear is that there is little incentive for him to employ a direct interventionist strategy to negate racial stereotypes at the group level. That strategy carries the potential cost of disrupting the impression of him as an affable racial minority and a good institutional citizen. ${ }^{69}$

\section{b. Indirect Intervention}

Is there an indirect way in which Marco might attempt to negate racial stereotypes at the group level? The most obvious way for Marco to do so is via his own work performance. More specifically, the quantity and quality of Marco's work may suggest to the firm's decisionmakers not only that Marco is a smart, hardworking, and conscientious worker but also that these characteristics apply to Latinos as a group. Marco's work performance might very well be outstanding enough to perform that signification. But,

69. On a related note, experimental research shows that when outsider group members are allowed even minimal entrance into the dominant group (that has a higher status), these outsider group members tend to strengthen identification with the group into which they seek entrance. See generally Naomi Ellemers, The Influence of Socio-Structural Variables on Identity Management Strategies, 4 EUR. REV. SOC. PSYCHOL. 27 (1993); Stephen Wright et al., Responding to Membership in a Disadvantaged Group: From Acceptance to Collective Protest, 58 J. PERSONALITY \& SOC. PsYCHOL. 994 (1990). All outsider group members, however, do not react to the opportunities for individual advancement versus group advancement equally. Those outsiders with lower levels of identification with the outsider group and who contest their being placed in the lower status group, as one might expect, are more willing to leave their fellow outsiders behind if presented with an opportunity for individual advancement. See Branscombe \& Ellemers, supra note 58, at 245, 257 (discussing studies about the identification levels of group members). The result then can be that these peripheral outsider group members (who are the ones most likely to advance) take on strategies that serve the interests of the dominant group and do not best advance the interests of their marginalized outsider group. See Carbado \& Gulati, supra note 18, at 1813 n.202 (citing to research by Stephen Wright and others in making this point); Brenda Major et al., Reducing Prejudice: The Target's Perspective, in REDUCING PREJUDICE AND DISCRIMINATION 211 (Stuart Oskamp ed., 2000) (discussing how people may not respond to social identity threats or negative stereotyping if the emotional energy required to respond to correcting those problematic perceptions is too high). See generally Michele Lamont, Everyday Anti-Racism: Competence and Religion in the Cultural Repertoire of the African-American Elite (May 3, 2001) (unpublished manuscript, on file with the Washington and Lee Law Review) (finding that successful and elite African Americans, while often espousing racial solidarity, often adopt strategies of self-presentation that are not truly inclusive, but instead only allow the advancement of a few minority group members to the privileged position of insiders). 
presumably, Latinos who can perform at this level-in other words, true superstars-are in short supply.

Assuming that Marco is not a superstar, he can still attempt to negate group-based stereotypes through the choices he makes about work. That is, Marco can be even more high-risk with respect to work assignments than he otherwise would be. The problem with this strategy is this: the greater Marco's risk-taking, the greater the possibility of large failure, failure which would confirm, rather than disrupt, racial stereotypes. The problem is compounded if other Latinos (or other minorities) in the firm adopt this strategy. The failure rate of the group will rise, creating the overall impression that Latinos or minorities are irrational and rash. The end result is an exacerbation rather than an elimination of negative racial presumptions.

Another problem with group-based negation strategies based on work performance is that most jobs do not involve tasks where the production of each employee can be separated and ranked against that of others. Instead, most high-level jobs tend to involve production in teams and fuzzy individual outputs. This limits the extent to which any one individual can, through the quality of his work, challenge racial stereotypes at the group level. At best, such individuals can preempt the application of the negative stereotype to themselves. Returning to our hypothetical, although Marco's work performance may have the potential to rebut assumptions about his competence and work ethic, it will be inadequate to the task to rebut negative assumptions about Latinos as a whole.

\section{Individual Identity Negation Strategies}

Given both the cost and difficulties of negating stereotypes at the group level, minorities may attempt to disrupt stereotypes at the individual level. The problem with this strategy is that it allows the firm's decisionmakers to engage in what we call racial exceptionalism. Consider Marco again. If Marco employs an individual identity strategy and succeeds, the institutional message would be: Marco may be a Latino, but he is not like other Latinos. He is exceptional. Therefore, the stereotypes we hold about Latinos should not be applied to Marco. Note that the firm has not revised its impressions of Latinos, only its impression of Marco. The problem is potentially worse. To the extent that Marco's individual stereotype negation strategy takes the form of racial distancing and disidentification, they exacerbate rather than ameliorate negative stereotypes about Latinos as a group. Assume, for example, that Marco might inform his majority colleagues that he is frustrated 
with the low standards of work among his fellow minorities and their failure to act as team players. ${ }^{70}$ There is little reason to conclude that this individual identity negation strategy will trickle down to benefit junior people of color.

70. There is a large literature on "outsiders" using distancing strategies to advance in the workplace. These distancing strategies can come in at least two forms. First, there can be distancing in that the employee might try to emphasize aspects of her identity that are the nonminority aspects. In other words, she may try to make her race less salient. So, if her colleagues are Catholic or from the same college that she went to or if they all play chess, she may try to emphasize those commonalities and deemphasize the racial and gender differentials. Alternatively, the minority employee might try to exceptionalize herself and comfort her colleagues about the negative views that they have about minorities. So, she may tell them that she also thinks that it is a problem that so many minorities are lazy and obsessed with race issues. Of the two strategies discussed above, the second one is obviously more harmful to the group's interest (because it involves the active confirmation of stereotypes). But the first strategy is also problematic in that it involves deemphasizing (making invisible) the race of the successful minority and, therefore, reducing the chances that success will be used by others to revise their views about the racial group.

Roberts articulates the distinction that we make above in terms of "assimilation" versus "decategorization." See Roberts, supra note 41 (manuscript at 25-26) (explaining the concepts of "assimilation" and "decategorization"). Assimilation refers to emphasizing distinctiveness from one's social group and similarities to the more dominant group. "Passing" is an extreme form of assimilationist behavior. Decategorization also involves reducing the salience of one's racial identity, this time by emphasizing the nonstigmatized portions of one's identity, such as one's identity as an engineer or sports fan or UCLA graduate. Similarly, avoiding issues of race in one's conversations is another method of achieving decategorization. See Thomas, supra note 53, at 178-80 (discussing how minorities may sometimes suppress race in order to develop relationships with mentors who are uncomfortable with racial issues). On both sets of strategies in a variety of contexts, including race, gender, and sexual orientation, see generally Donna Chrobot-Mason et al., Sexual Identity Management Strategies: An Exploration of Antecedents and Consequences, 45 SEX Roles 321 (2001); John F. Dovido et al., Reducing Contemporary Prejudice: Combating Explicit and Implicit Bias at the Individual and Intergroup Level, in REDUCING PREJUDICE AND DISCRIMINATION 137 (Stuart Oskamp ed., 2000); Naomi Ellemers et al., Self and Social Identity, 53 ANN. REV. PsYCHOL. 161 (2002); Teresa LaFromboise et al., Psychological Impact of Biculturalism: Evidence and Theory, in THE CULTURE AND PSYCHOLOGY READER 489 (Nancy Rule Goldberger \& Jody Bennet Veroff eds., 1995); Robin J. Ely, The Effects of Organizational Demographics and Social Identity on Relationships Among Professional Women, 39 ADMIN. SCI. Q. 203 (1994) [hereinafter Ely, The Effects of Organizational Demographics]; Robin J. Ely, The Power in Demography: Women's Social Constructions of Gender Identity at Work, 38 ACAD. MGMT. J. 589 (1995); Laurie A. Rudman, Self-Promotion as a Risk Factor for Women: The Costs and Benefits of Counterstereotypical Impression Management, 74 J. PERSONALITY \& SOC. PSYCHOL. 629 (1998); Laurie A. Rudman \& Peter Glick, Feminized Management and Backlash Toward Agentic Women: The Hidden Costs to Women of a Kinder, Gentler Image of Middle Managers, 77 J. PERSONALITY \& SOC. PSYCHOL. 1004 (1999). 


\section{B. Racial Monitoring}

Recall our assumption that the presence of successful minorities would have the effect of racially monitoring the institution. ${ }^{71}$ White colleagues, we posited, would be more likely to be conscious of racial issues in making decisions in the presence of their successful minority colleagues than they would in their absence. This accountability effect could impact both the firm's labor market decisions, including those relating to promotion and hiring, and its nonlabor interactions with the outside world, including choices about what products to manufacture, how to market them, and others. Our aim here is to question this racial monitoring assumption.

Imagine that Marco has just been promoted to partner. Assume that hiring decisions are made by partners, that Marco is about to participate in his first hiring meeting, and that he is only one of two minorities present. Will Marco's presence have a monitoring effect? There are several reasons to answer that question in the negative. First, Marco has likely participated in numerous socialization rituals in which his racial palatability was both demanded and supplied. Indeed, Marco's very success within the firm was probably a function of his capacity to practice racial comfort and individual identity stereotype negation. ${ }^{72}$ Members of the partnership, then, would not feel excessively racially policed by Marco's presence.

Second, to the extent that this is Marco's first partnership meeting about hiring, there is an incentive for him to use the moment to assure his partners that his status as a partner will inaugurate a change neither in his institutional nor in his racial identity. In other words, Marco might view this meeting as a high visibility moment in which he, as a partner, needs to demonstrate institutional fit, loyalty, and team orientation. ${ }^{73}$ Further, he would want to find a way to convey the idea that he is not interested in disrupting the selection

71. See supra Part II.B (discussing how the presence of minorities affects decisions throughout the firm).

72. See Carbado \& Gulati, supra note 19, at 1803-06 (suggesting that firms employ selection mechanisms to hire people of color who they believe will provide racial comfort).

73. In her classic work, Kanter describes this (in the gender context) as women being subject to "loyalty tests" where, as a requirement of fitting in, women are expected to put down other women on occasion. Kanter describes three ways in which women can pass loyalty tests: they can let slide biased statements about other women, they can allow for jokes about women to be made without resistances, and they can accept their situation. See KANTER, supra note 48, at 227-29 (explaining loyalty tests); see also Ramit Mizrahi, Note, "Hostility to the Presence of Women": Why Women Undermine Each Other in the Workplace and the Consequences for Title VII, 113 YALE L.J. 1579, 1602 (2004) (suggesting the continued applicability of Kanter's work to the gender discrimination context today). 
and socialization processes that (racially) produced him. This would send a message to the partners that Marco is willing to help the firm "manage" other racial minorities and residual racial differences. The foregoing suggests there is reason to believe that Marco's presence would not operate as a racial monitor. This conclusion is not undermined by the risk-taking aspects of Marco's identity, which, again, is (a) directed at work assignments and (b) a part of a broader strategy to disconfirm or negate racial stereotypes.

\section{Racial Accountability}

Another assumption we made about minority survivors of the promotion tournament is that they would produce racial accountability. The idea, again, is that the presence of these minorities would require the firm to account forexplain or justify-apparent racial inequities in the firm. ${ }^{74}$ The reasons articulated above as to why senior people of color may not produce racial monitoring also explain why racial accountability may not occur. In short, the firm would have an expectation that the people of color it promotes (a) are committed to the institutional norms of the firm, even norms that have disparate racial impacts such as those relating to hiring and promotion, and (b) would have an investment in demonstrating that commitment. ${ }^{75}$ As a result,

74. See supra Part II.C (explaining the concept of racial accountability).

75. Patricia Hewlin and Ashley Rosette, in a recent paper, argue that even white male employees will often feel pressured to avoid pointing out instances of discrimination (even while thinking that it is wrong) so as to avoid being stigmatized as nonteam players. See generally Patricia Faison Hewlin \& Ashleigh Shelby Rosette, Stigma Avoidance: A Precursor to Workplace Discrimination (Aug. 2004) (unpublished manuscript, on file with the Washington and Lee Law Review). Hewlin and Rosette draw on a larger literature on organizational silence. For examples of articles in this area, see generally Frances J. Milliken et al., An Exploratory Study of Employee Silence: Issues That Employers Don't Communicate Upward and Why, $40 \mathrm{~J}$. MGMT. Stud. 1453 (2003); C.C. Pinder \& Karen P. Harlos, Employee Silence: Quiescence and Acquiescence as Responses to Perceived Injustice, 20 RES. HUM. RESOURCES \& PERSONNEL MGMT. 331 (2001); Janet P. Near \& Marcia P. Miceli, Whistle-Blowers in Organizations: Dissidents or Reformers?, 9 RES. ORG. BEHAV. 321 (L.L. Cummings \& Barry M. Straw eds., 1987). In the context of studying the disclosure securities practices of organizations, Langevoort taps the management literature to understand how and why it is that lower level employees are often reluctant to report bad news to their superiors (and, indeed, will often spin the news in a positive fashion so as to please their superiors). See generally Donald C. Langevoort, Organized Illusions: A Behavioral Theory of Why Corporations Mislead Stock Market Investors (and Cause Other Harms), 146 U. PA. L. REV. 101 (1997).

There are at least two other dynamics that can also produce this silencing. One of them is where those who have been promoted feel a sense of obligation to the organization for having promoted them and, therefore, remain silent in the face of injustice. See KANTER, supra note 48, at 229 (explaining how women demonstrate loyalty). The other relates to the perception of 
the presence of minority seniors would not necessarily exert any pressure on the firm's decisionmakers to account for racial disparities or inequalities within the firm.

\section{Racial Cooperation}

Earlier we posited that the presence of senior minorities would facilitate racial cooperation. The notion was twofold. First, seniors would provide input into the formation of teams to maximize opportunities for racial trust; and second, their very success would eliminate or mitigate racial anxieties and suggest to nonwhites and whites alike that racial cooperation is possible. ${ }^{76}$ Here again the question is whether these theoretical benefits are realizable. The short answer is only marginally so.

Minorities who survive promotion tournaments are not likely to be actively engaged in race-conscious structuring of teams. Their firm socialization would suggest to them that, both normatively and pragmatically, this is a bad thing to do. It would render their own racial identities more salient and less palatablein other words, weaken their institutional fit. Further, to the extent that these seniors have worked hard without the intervention of others to demonstrate their capacity for racial cooperation, they may expect other minorities to do the same.

the institution as a just, fair, or meritocratic place. Research shows that those who hold these "just world" beliefs are less likely to perceive discrimination. See Cheryl R. Kaiser, Dominant Ideology Threat and the Interpersonal Consequences of Attributions to Discrimination, in STIGMA AND GROUP INEQUALITY: SOCIAL PSYCHOLOGICAL APPROACHES (C. van Laar \& S. Levin eds., forthcoming 2005) (manuscript at 11-12, on file with the Washington and Lee Law Review) (discussing the "study examining individual differences in chronic endorsement of the [Belief in a Just World]"); Brenda Major \& Cheryl R. Kaiser, Perceiving and Claiming Discrimination, in THE HANDBOOK OF EMPLOYMENT DISCRIMINATION (L.B. Nielsen \& R. Nelson eds., forthcoming 2005) (manuscript at 13-15, on file with the Washington and Lee Law Review) (examining the "[b]elief systems that justify hierarchical and unequal relationships among groups in society"). Conversely, research also suggests that outsiders who attribute negative events to discrimination, even when those events are blatant, are likely to be perceived as troublemakers, that is, hypersensitive and irritating). See Cheryl R. Kaiser \& Carol T. Miller, Derogating the Victim: The Interpersonal Consequences of Blaming Events on Discrimination, 6 GROUP PROCESSES \& INTERGROUP REL. 227, 234-36 (2003) (discussing results of experiment).

Given the foregoing, it seems reasonable to predict that an institution will have an interest in promoting those who both feel grateful to the institution for promoting them and those who perceive the institution as meritocratic and fair. These individuals, after all, are going to be less likely than others to perceive discrimination.

76. See supra Part II.D (explaining the concept of racial cooperation). 
Nevertheless, there will probably be some marginal racial cooperation payoff from the presence of successful senior minorities. Their presence will suggest that people of color-of a particular type-can work cooperatively with whites. To the extent their presence conveys this message, it is unlikely that the firm's decisionmakers will adopt a per se position that people of color are incapable of working cooperatively with whites. Instead, they are likely to have a presumption against this possibility which could be rebutted to the extent that the nonwhites in question are of the same racial type as the ones who survived the promotion tournaments. This is the sense in which the racial cooperation payoff from the presence of successful senior nonwhites is likely to be marginal.

\section{E. Racial Comfort}

A related assumption we made about the benefits of senior people of color in predominantly white corporate cultures is that they will reduce the supply of and demand for racial comfort work. The thinking was that the presence of senior people of color would diminish anxieties about racial difference, thus reducing the need for juniors to supply racial palatability. ${ }^{77}$

Just the opposite may be true, however. Recall our suggestion that minorities who succeed in climbing the corporate hierarchy will probably have performed individually centered stereotype negation strategies-that is, strategies that reduce the extent to which the firm's decisionmakers will apply racial stereotypes to them. ${ }^{78}$ These strategies do not challenge racial stereotypes generally but rather challenge their applicability to particular individuals. Consequently, even with the presence of seniors who survived several promotion tournaments, the firm's decisionmakers will still base their hiring and promotion decisions on the idea that, as a general matter, racial differences cause grit not grease. They will thus continue to scrutinize junior minorities for their capacity to supply grease-that is to say, comfort. The greater the presence of racial comfort at the senior level, the greater the expectation that racial comfort should be supplied at the junior level. Keep in mind that, for efficiency reasons, there is already an incentive for the firm to achieve sameness. ${ }^{79}$ As we discuss elsewhere, to the extent possible, firms will want to realize the efficiency gains of sameness while maintaining some

77. See supra Part II.E (discussing racial comfort).

78. See supra Part IV.A.2 (explaining individual negation strategies).

79. See Carbado \& Gulati, supra note 19, at 1788-1802 (discussing the homogeneity incentive). 
degree of racial diversity. ${ }^{80}$ The success of racially palatable seniors creates racial precedent for what one might call skin-deep racial diversity; diversity that, in terms of identity performance, does little to disrupt or to contest the institutional and white-privileging norms of the firm. Rather than reducing the demand for racial comfort then, the presence of successful minorities might actually increase it.

\section{F. Role Modeling}

Our assumption about role modeling was that the presence of people of color at the top of the corporation would send a message to people of color at the bottom that they can have a successful place at the top. But once we particularize the discussion so that we are no longer discussing the generic category "people of color" and the simple fact of racial presence but discussing instead racial types and racial performance, it becomes less clear that the people of color at the top of the corporation will function as racial models for the people of color on the bottom. Part of what we have suggested is that the nonwhites who make it to the top of the corporation are likely to be racially palatable. Thus, they will not have evidenced an institutional identity that signifies racial group connectedness or affinity. Indeed, there are incentives for the successful racial types (again, the racial minorities at the top of the corporate hierarchy) to practice disassociation, disidentification, and differentiation. ${ }^{81}$ In other words, there are incentives for them to perform individual stereotype negation strategies to signal that they are not like, and do not wish to associate with, other racial minorities. To the extent that these strategies are performed, the people at the bottom of the corporation are not likely to have a racial connection with or to experience a role model effect from those at the top.

The foregoing argument assumes that the minorities at the bottom of the corporation will be racially invested in forging a racial connection with those at the top. However, this may not be the case, particularly if the corporation is successful in screening for racial palatability. The more successful the corporation is at performing this screening, the less likely that there will be racial tension or disconnection between the people of color at the top of the corporation and those on the bottom. Concretely, if Marco, a junior Latino executive, was the product of the corporation's successful screening for racial palatability, he

80. Id.

81. See Devon W. Carbado, Straight Out of the Closet, 15 BERKELEY WoMEN's L.J. 76, $116(2000)$ (referring to disassociation, disidentification, and differentiation as the "the politics of the 3Ds"). 
will probably not be concerned that Pablo (who goes by Paul) does not seem to be interested in or motivated by racial group affinity. Indeed, Marco might experience Paul as a role model precisely because Paul lacks this kind of racial investment. Thus, there is quite possibly a role model signal that derives from the presence of successful racial types. But the message this signal conveys is not about the success of racial difference but rather the success of racial palatability.

\section{G. Tokenism}

With respect to tokenism, our assumption was that minority survivors of the promotion tournament are likely to reduce the costs of tokenism-the weight of representing one's race and a diminishment in one's sense of workplace autonomy and belonging. ${ }^{82}$ Once again, there is reason to question this assumption. Consider first the burden of racial representation. Assume once more that Marco has just been promoted to the partnership. If one of the reasons the partners promoted Marco is that they perceived him to be different from other Latinos, his presence will do little to reduce the racial representation burden of junior Latinos. They too will have to prove that they are not like other Latinos, and they assume the risk that their job performance and overall institutional identity will suggest that they are. In other words, precisely because Marco's promotion was based, at least in part, on racial exceptionalism, other Latinos will have to prove either that they, like Marco, are exceptional or that racial stereotypes about Latinos are inaccurate. Marco's success, therefore, will not necessarily ameliorate the racial representation burdens of junior Latinos.

Nor is Marco's success likely to increase the workplace autonomy or sense of belonging of junior Latinos. To the extent that juniors will continue to worry about stereotypes and, more specifically, experience pressure to repudiate them, their autonomy to navigate the workplace is circumscribed. This is because the freedom junior Latinos have vis-à-vis their workplace interactions is a function of their sense that they are subject to negative racial stereotypes. The stronger this sense, the weaker their workplace autonomy. Marco's status as a racial exception affects this dynamic. Paradoxically, the more entrenched the firm's perception of Marco as a racial exception, the heavier the burden on junior Latinos to repudiate negative stereotypes. The racial logic of this dynamic derives from the

82. See supra Part II.F (discussing tokenism). 
simple notion that, by definition, exceptions are not the norm. The firm's decisionmakers could conclude that if Marco is the exception, the others are not. To make this more concrete, if in addition to Marco, there are two other Latinos at the firm, the firm's decisionmakers would be asking themselves: How likely is it that we have three racially exceptional Latinos working for us? The fewer the number of junior Latinos, the stronger the firm's impression that if Marco is a racial exception, the others are not. In this way, Marco's perceived exceptionalism might actually decrease rather than increase the workplace autonomy of junior Latinos. Because of his exceptionalism, juniors will have to structure their workplace interactions to rebut the presumption that, unlike Marco, they are not racial exceptions.

\section{H. Mentorship}

As discussed earlier, the first few generations of successful minorities likely had trouble finding mentors; people who would transfer to them not only the tacit knowledge required to excel at their jobs, but also an understanding of the informal norms and politics of the workplace essential for institutional survival and advancement. ${ }^{83}$ But how likely is it that those who made it despite the lack of mentorship will mentor successive generations?

At least two of the characteristics of successful racial types suggest that the answer is "not very likely": overconfidence and the need to demonstrate affinity for the dominant group. Consider overconfidence. A successful racial type likely has a firm belief that he deserves his success and that it was not a product of chance or circumstance. ${ }^{84}$ This overconfidence enables the minority who uses high-risk strategies to succeed and to persuade others that his success was not the product of chance but of merit. The problem this overconfidence presents with respect to mentoring is this: a person of color who succeeds without mentoring may believe that other minorities do not or should not need any mentorship; after all, he made it on his own merit. He may even construe affirmative mentoring as "special help," help that could function to confirm the very stereotypes he spent much of his time attempting to disrupt.

83. See supra Part II.G (discussing mentorship and the network of information).

84. See Anderson, supra note 68 , at 12 ("For . . . blacks [at the higher status levels of an organization] there is a strongly felt need to believe they are present in the organization not solely because of the color of their skin but because of their own excellence in the general business world."). 
The second dynamic that cuts against mentorship is the need for the successful minority to continually demonstrate that she is a team player. Sharing her human capital with other minorities might suggest that she is a racial group or special interest player. If the senior minority perceives that her colleagues are scrutinizing her mentorship choices for signs of racially specific mentorship, she may consciously seek to avoid mentoring too many or, indeed, any minorities.

A final reason why senior minorities might not mentor juniors derives from the investment on the part of seniors in continued corporate success. If a senior perceives that minority juniors have a poor success rate, and if having a stable of successful mentees is important to one's long term success, there is a disincentive for the senior person of color to mentor junior nonwhites. ${ }^{85}$

\section{Conclusion}

We began our Article with a particular construction of workplace hierarchy. Central to this construction is the idea that an employee's ability to race to the top of the corporation is not solely a function of traditional qualifications and capability. In other words, producing more widgets than one's competitors is not enough. To succeed, employees have to effectively negotiate the political landscape of the institution. That is to say, they have to appease individual corporate officers, co-opt and make allies with powerful interest groups, and undermine competitors. The more bureaucratic the organization and the more opaque the promotion process, the more important this institutional game is to climbing the corporate ladder.

Broadly stated, our aim has been to identify the kind of racial types who are likely to play this game well and, consequently, race to the top of the corporation. Our thinking was that, because the racial minorities at the top of the corporation are in an institutional position to perform discrimination-

85. The phenomenon of inadequate mentorship by outgroup members has been observed at length in the literature on gender. See Mizrahi, supra note 73, at 1590-92 (examining the phenomenon of "female-on-female workplace hostility"). More broadly, see generally PAT HEIM \& SUSAN MURPHY, IN THE COMPANY OF WOMEN: TURNING WORKPLACE CONFLICT INTO POWERFUl Alliances (2001). Research by scholars such as Ely and Thomas, however, suggests that there is nothing necessary about this dynamic. See generally Ely and Thomas, Cultural Diversity at Work, supra note 63. Organizations can be structured in ways that women (and other outsiders) are comfortable enough in their difference that they are able to help others of their group. See Ely, The Effects of Organizational Demographics, supra note 70, at 206 ("In settings in which women can perceive their group favorably relative to men, as when there is evidence of women's advancement, women's identifying with women will be a positive experience and can serve to strengthen relationships among them."). 
ameliorative tasks for those on the bottom, identifying these racial types is crucial to making corporations more welcoming to, and comfortable for, racial minorities. It is this intuition that helps to explain why many corporate governance and employment discrimination scholars rest some of their hope for the establishment of colorblind corporate cultures on the assumption that successful racial types will actively seek out and perform antidiscriminatory institutional work.

As we have shown, however, there is reason to believe that the racial minorities at the top of the corporate hierarchy will neither racially reform the corporation, nor engage in door-opening activities, for the minorities on the bottom. Indeed, strong incentives exist for minorities to race to the top of the corporation and pull the ladder up behind them when they get there. Our project has been to set forth the nature of these incentives, reveal how they help to produce particular racial types, and explain why these racial types might not have the racial commitment, or feel institutionally empowered, to lift as they climb.

The question now is: What does the foregoing have to do with law? Antidiscrimination law, for the most part, is structured to protect individuals from intentional animus. But, as many have pointed out, much discrimination operates beneath the surface, at the subconscious and unconscious levels. ${ }^{86}$ Despite this shortfall in the law's coverage, there is an optimistic narrative that one can tell: The imposition of barriers against explicit exclusionary practices, along with changes in social norms regarding the unacceptability of intentional animus, means that at least some racial minorities will be allowed into the executive suite. The success and presence of these few in positions of power will result in crossracial learning and appreciation and, eventually, will lead to the amelioration of unconscious and subconscious discrimination. At the same time, the people of color at the top of the corporation will extend the corporate ladder to those at the bottom.

The combined effect of these dynamics is greater corporate diversity. If one adds to this corporate diversity story the standard economic narrative that the market will drive out racist corporate conduct (racism is inefficient), one could reasonably conclude that there need not be an antiracist rush to change the legal standards and evidentiary burdens of employment discrimination law.

Our preliminary examination of (1) the types of racial minorities likely to climb the corporate ladder, (2) the racial conditions of their climb, and (3) what they do when they arrive at the top, suggest that, perhaps more than ever, law is

86. The classic articulation of the thesis is Lawrence, The Id, supra note 24; Krieger, supra note 24. 
needed. Successful senior minorities cannot be expected to do the antidiscrimination work that law, albeit imperfectly, has historically performed. The difficulty is in articulating a coherent antidiscrimination theory to doctrinally manage the problems of homogeneity, racial palatability, and negative stereotyping. ${ }^{87}$ For unless we change the racial terms and conditions upon which people of color race up the corporate ladder, we cannot but expect them to pull the ladder away when they arrive at the top.

That cynical and skeptical note takes us back to whence we began-to the lives of Jerome Culp and Marilyn Yarborough. The stories of their lives, ones that we hope their colleagues and friends will document in detail, is that the portrait of minority success is so much more complicated and nuanced than the one we have painted. There are those among the first generations of successes, like Jerome and Marilyn, who transcended the desire for personal success and instead sacrificed repeatedly for the welfare of others. They lifted many as they climbed. We will remember them. We will continue to speak their names. And, we will always miss them. 42.

87. For a preliminary effort in that direction, see generally Carbado \& Gulati, supra note 
